Historic, Archive Document

Do not assume content reflects current scientific knowledge, policies, or practices. 
of of Traey of

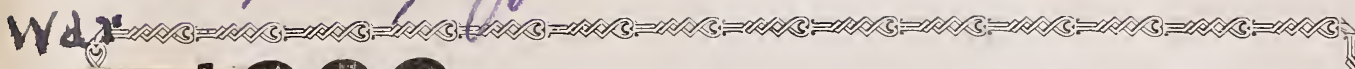
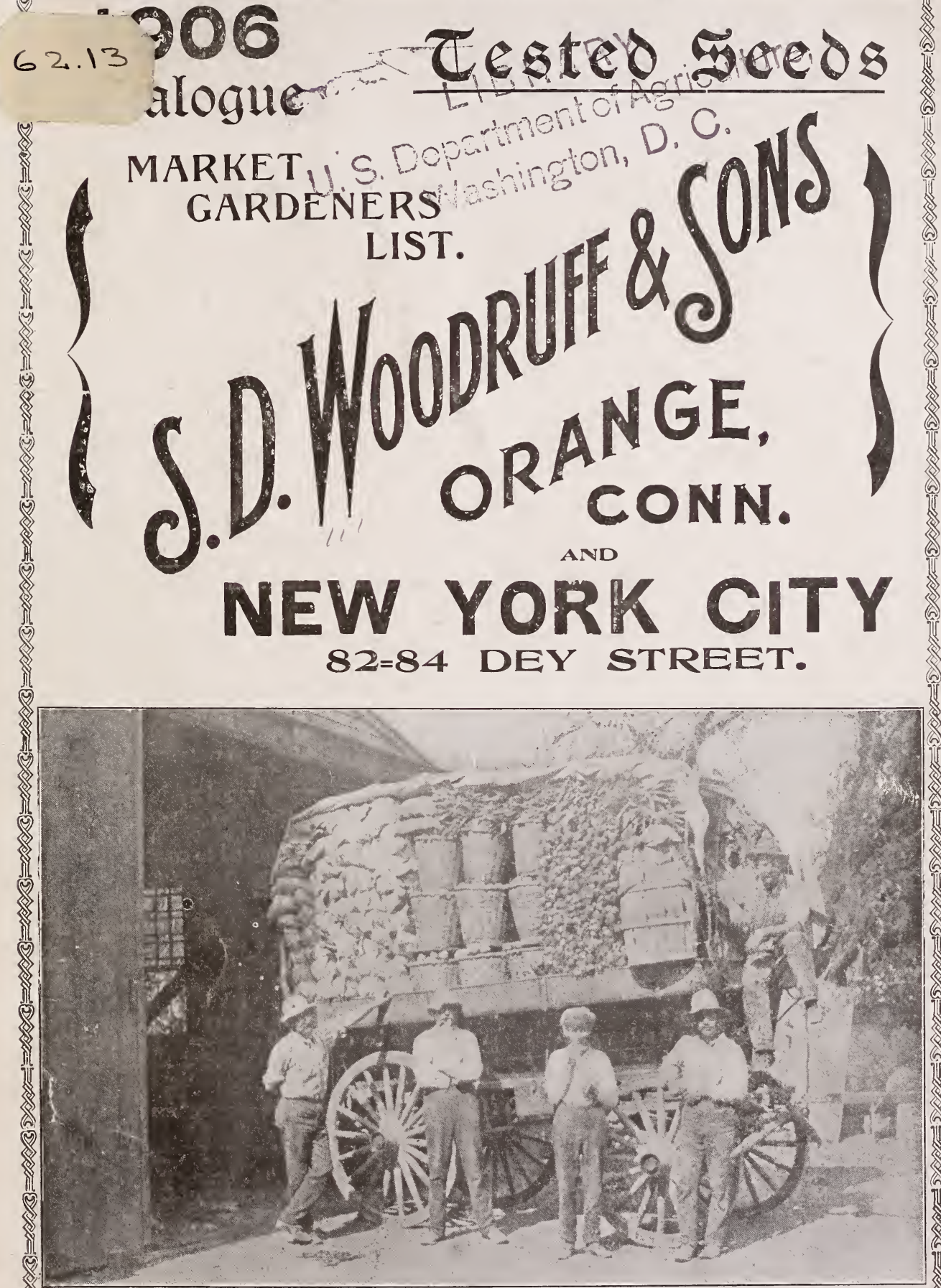

Photograph of a load of Vegetables which brought over $\$ 100,00$ on the New York Market last June and is one of many such grown exclusively from Woodruff's Seeds.

Send your order to nearest point, Orange, Conn., or New York City.

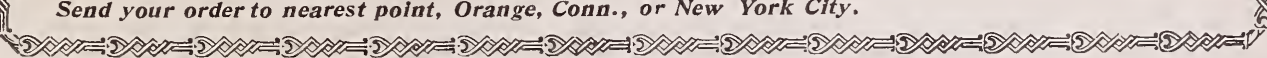




\title{
SEED CATALOGUE 1906
}

\section{S. D. Woodruff \& Sons,}
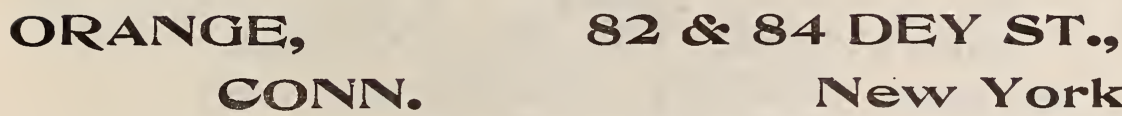

New York City.

\author{
Please order from nearest point either New York or Orange.
}

\section{'TO OUR CUSTOMERS}

In placing before you this little book which we trust will impress you as containing PLAIN FACTS ABOUT PURE SEEDS, we desire to thank you first of all for the patronage you have given us in the past, particularly during the past season which was as you perhaps already know the banner year for Woodruff's Seeds. We assure you we have tried to arrange to handle your orders during the coming season more promptly than ever before and to that end we have decided to keep our NEW YoRK STORE OPEN ALL THE YEAR ROUND. Those of our customers who can do so are cordially invited to call there whenever in New York. They will always find us glad to see them and willing to do anything in our power to help them.

So great has been the demand for our seeds on Long Island, "The Garden Spot of the World," that we have leased and opened Dec. I, a large sales warehouse at Queens, L. I. We have enlarged our buildings at Orange, Ct., and have erected and filled with choice seed potatoes two more large storehouses in Aroostock County, Maine. (We now have six there.)

Our Seed Potatoes ARE All Grown in Maine under the personal supervision of our EXPERT SALARIED managers, and have a national reputation for purity and big yield. Potatoes grown in this manner necessarily cost more than ordinary market stock, but the fact that we have among our customers brother seedmen and dealers who buy one to five carloads each is sufficient evidence of our superior quality seed.

We are lifelong seed growers. Our seed farms at Orange, Ct., where the members of our firm live are open to the inspection of our customers and friends. You are always welcome to visit us either at our New York Store, 82 and 84 Dey Street, N. Y., or at our farms at Orange, New Haven County, Conn.

\section{HOW TO SEND MONEY.}

We will receive postage stamps, if received in good condition, same as cash. Remit by P. O. or Express Money Order or Registered Letter.

\section{POSTAGE.}

Seeds will be mailed postpaid in quantities of $\mathrm{I}-4 \mathrm{lb}$. and less. Quantities of $\mathrm{I}-2 \mathrm{lb}$. and over will require postage at the rate of 8 cents per $1 \mathrm{~b}$. in addition to catalogue prices. Peas and beans require I5 cents per quart, and corn ro cents per quart in addition to catalogue prices.

\section{WE PAY THE PREIGHT.}

On orders to the amount of $\$ 7.00$ or over, at catalogue prices, where cash accompanies orders, we will deliver goods to your nearest station, charges prepaid. Excepting we cannot pay freight on potatoes or onion sets.

\section{DISCOUNTS.}

Market gardeners who purchase ten, twenty or more dollars' worth of seeds naturally expect a lower price than those who purchase but a small amount, and we will make the following discounts from catalogue prices, where cash accompanies order; on seeds in packets and by the ounce, we will mail, postpaid, for one dollar, seeds to the amount of one dollar and twenty-five cents. On orders amounting to ten dollars and upwards, deduct 5 per cent., where cash is sent with order, except on 


\section{S. D. WOODRUFF \& Sons,}

Orange, Conn., 82 and 84 Dey St., New York.

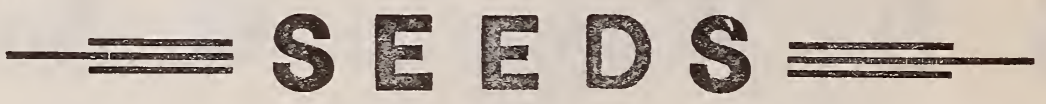

\section{GROWER TO PLANTER.}

SPECIAL MARKET GARDENERS' LIST.

\section{N. B. Our New York City Store is open all year round.}

\section{ASPARAGUS.}

Prices, pkt., 5c.; oz., IOc.; $\frac{1}{4}$ lb., I5c.; lb., 40c.; five pounds and over at 35c. 1b.

$\checkmark$ Conover's Colossal. The standard and best known variety, white tipped.

$\checkmark$ Palmetto. Very early, large and pale green, purple tipped, b'eaching elegantly, and closely resembling the finest French product.

$\checkmark$ Barr's Mammoth. Large and fine, white tipped.

Price of following, pkt., $5 \mathrm{c}$.; oz., IOc.; $\frac{1}{4}$ lb., $20 \mathrm{c}$; 1b., 6oc: 5 lbs. and over at $50 \mathrm{oc} . \mathrm{b}$.

$\checkmark$ Columbian Mammoth White. Very large pure white tips.

$\checkmark$ Giant Argenteuil. An improved selection fron French Argenteuil.

\section{ASPARAGUS ROOTS. (All 2 year old strong roots.)}

Palmetto,

Conover's Colossal,

Columbian Mammoth White, per 100 per 1000

$\begin{array}{lrl}.70 & \$ 3.75 & \text { Barr's Mammoth, } \\ .60 & 3.50 & \text { Lomaid's Elmira, } \\ .70 & 3.75 & \text { Giant Argenteuil, }\end{array}$

(Special prices on large lots.) per 100 per 1000 $.70 \quad \$ 3.75$

$.70 \quad 3.75$

$.70 \quad 3.75$

\section{BEANS.}

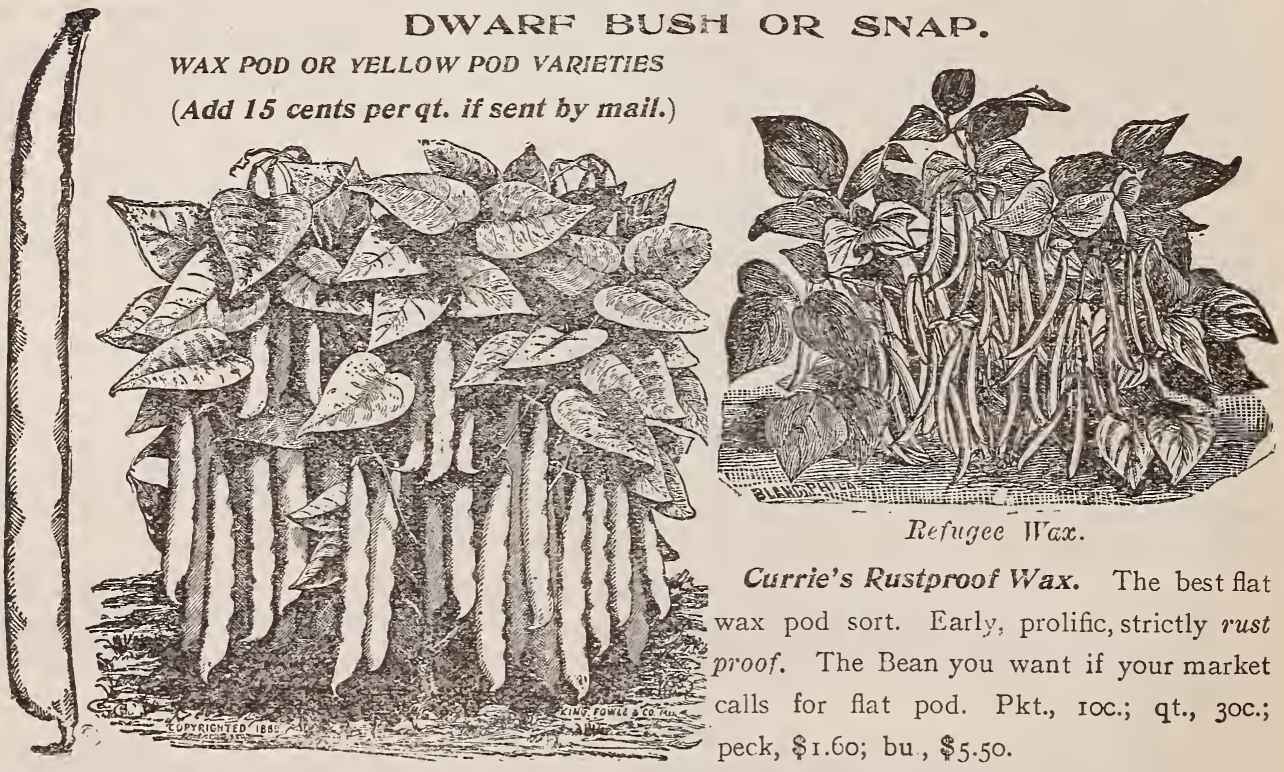

Currie's Rustproof Wax Bean.

Stringless Refugee Wax. The best round podded variety. Sure to yield an early and profitable crop The strain of seed we offer is pure, not mixed with Green Beans. Pkt., roc.; qt., 30c.; pk., \$ r. 5 O; bu., $\$ 4.50$.

All beans we offer are of the finest hand-picked stock. None are better and few are equal in purity. Note our discounts on page 1, in comparing prices. 
Beans-continued.

Stringless Refugee Wax.

Per pkt. \$.IO

Davis' White Kidney Wax

Per qt. $\$ .30$

Per pk.

$\$ \mathrm{I} .50$

I.80

I. 60

I. 80

I. 60

I. 60

Improved Rustproof Golden Wax

.25

.25

.25

I. 60

I 60

Black Wax (Dwarf German Wax) (round pod)

Prolific Black Wax (round pod)

California Wax.

\section{DWARF OR BUSH.}

\section{GREEN PODDED VARIETIES.}

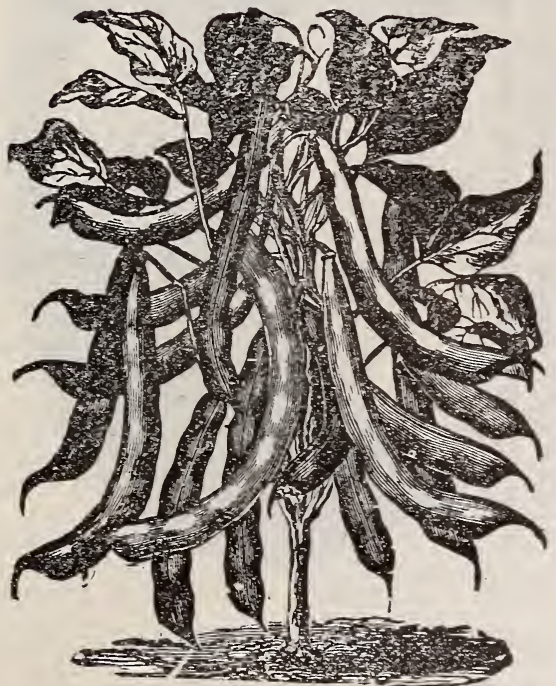

Refugee 1000 to 1.

Black Valentine. A new bean, very early, round pod, light grcen color. May be sowed quite early as the seed stands cold weather well. Seed very short crop this year. Pkt., Ioc.; qt., 25c.; pk., \$1.70; bu., \$6.00.

Bountiful. Flat pod

Longfallow. Round long pod.

Black Valentine

Early Long Yellow Six Weeks. Flat pod .....................................................

Early China Red Eye. Flat pod........................................................................... ... .05

Early Mohawk. Flat pod.

Early Red Valentine. Improved round pod ................................................... .05

Extra Early Refugee. Round pod....................................................................... .05

Refugee or 1000 to 1. Round pod.................................................................... .05

Burpee's Stringless Green Pod. Round pod................................................. .I0

Mammoth Stringless Green Pod. Crop failed.

Dwarf Horticultural.

Goddard or Boston Favorite

Lowe's Champion Bush

Royal Dwarf or White Kidney.

White Marrowfat.

White Medium. Common field beans.
Plit. qt. pk. bu.

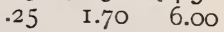

$.25 \quad$ I.70 6.00

$\begin{array}{lll}.20 & \text { I. } \\ .20 & 4.00\end{array}$

$.20 \quad$ I.IO 4.00

.20 I.IO 4.00

$.20 \quad$ I. $40 \quad 4.00$

$\begin{array}{lll}.20 & \text { I. } 40 \quad 4.50\end{array}$

$.25 \quad \mathrm{I} .75 \quad 5.50$

.20 $\quad \overline{1.40} \quad \overline{5.00}$

$.20 \quad$ I.OO 3.75

$.30 \quad$ I.40 4.50

$\begin{array}{lll}.20 & .90 & 3.25\end{array}$

$\begin{array}{lll}.10 & .90 \quad 3.50\end{array}$

.10 $\quad .90 \quad 3.00$
$\$ .25$ \$i.30 $\$ 4.50$

$.20 \quad$ I. $40 \quad 4.00$

\footnotetext{
In comparing prices note that we deliver seeds to your station without extra charge, provided your order anounts to $\$ 7.00$ or over, where cas accospanies order.
} 


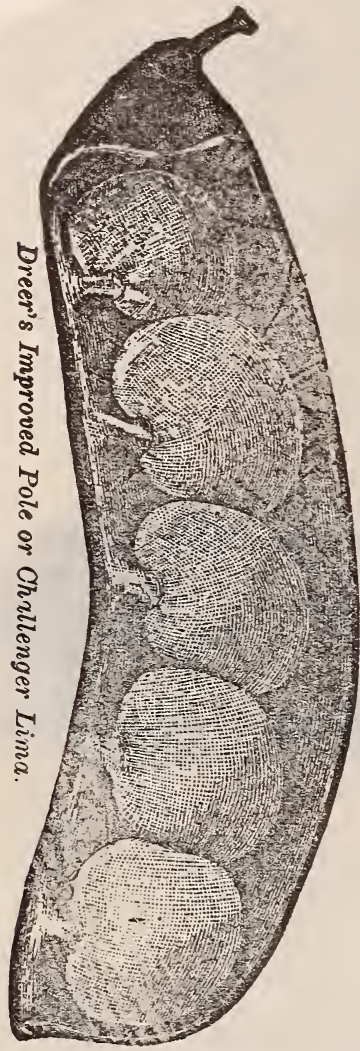

\section{LIMA BEANS.}
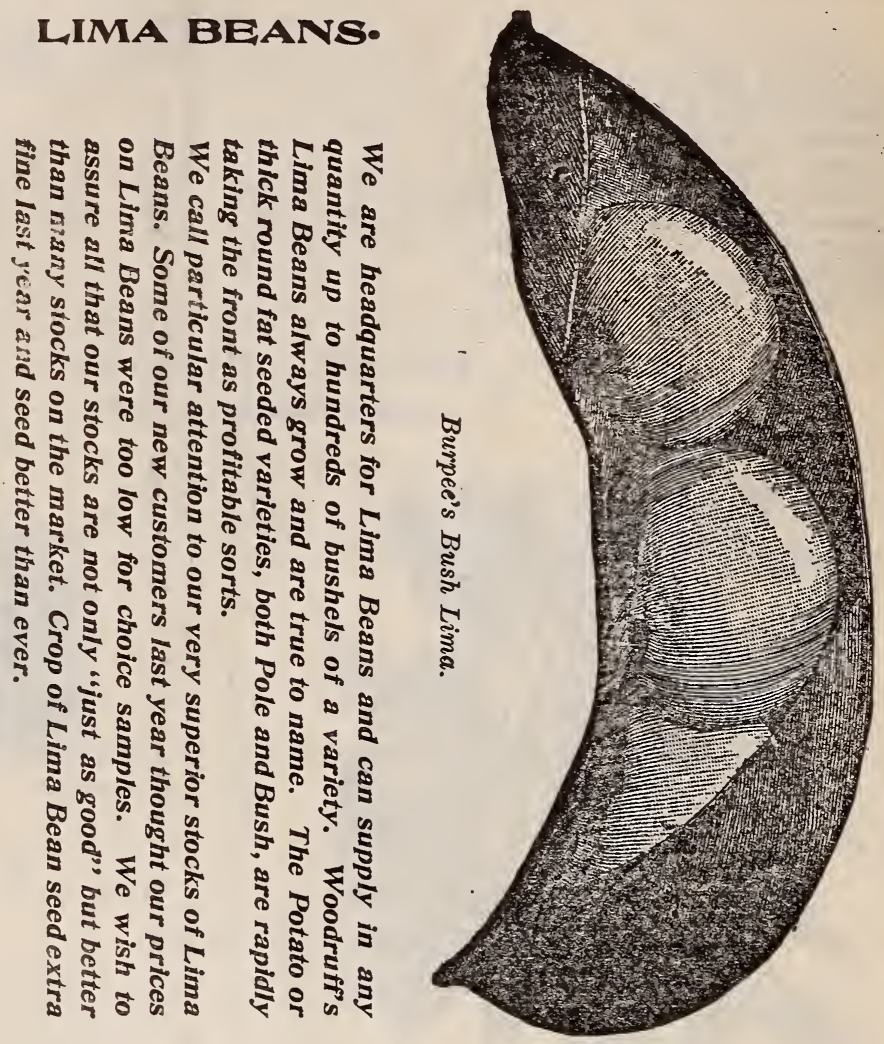

Fote our very low prices and in comparing prices note discounts on page $\mathbf{I}$.

\section{BUSH LIMAS.}

All Bush Limas, roc. pkt.; 30c. qt.; \$1.70, peck.

Burpee's Bush Limas..

Dreer's or Potato Bush Limas.

bu.

8 bu.

Henderson's Bush Lima.

$\$ 5.75$

5.75

\section{VARIETIES OF POLE LIMA BEANS.}

Pkts. of each, IOc.; pint, I5c.; qt., 25c.; peck, \$I.jo.

Seibert's Early Lima.

bur.

Large White Lima

$\$ 5.00$

5.00

Extra Large White Lima

King of the Garden. Early and very productive

$5 \cdot 50$

Early Jersey. True stock.

5.00

Ford's Mammoth. Immense pods............. 5.00

Early Leviathan...

ba.

Dreer's Improved. Round and thick bean ................ 5.50

Challenger or Potato Lim \&......................... 5.50

White Dutch Runners.................................... 5.50

Scarlet Runners. Grown principally for ornament. 5.00

\section{POLE OR RUNNING BEANS.}

Packets of each, IOc.; pints, I5c.; qr., 25 c.

Dutch Case Knife. Pods long, green and flat

Old Homestead or Kentucky Wonder. Pods long, green, round; excellent snap bean.... $1.40 \quad 5.00$

White Creaseback. Extra early; green pod............................................................................... $1.50 \quad 4.75$

Horticultural Cranberry or Wren Egg. Either a ssap or shell bean................................ $1.25 \quad 4.50$

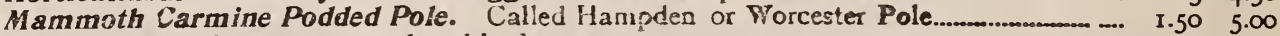

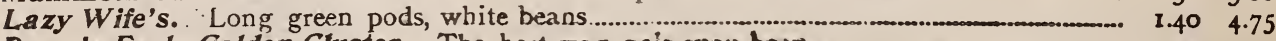

Dreer's Early Golder Cluster. The best was poie swap boul 


\section{BEETS.}

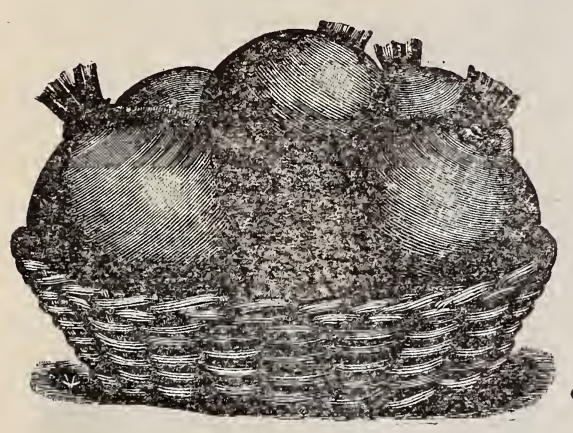

Crimson Globe Beet.

One of the special crops on our Orange Seed Farms is Leet Seed. Every new sort introduced is there carefully tested and the list which follows contains the best of both the new and old standard sorts.

For Early Use. For Summer. For Fall Sowing. Crosby's Egyptian, Detroit Dark Red, Eclipse,

Dirigo. Lentz, Edmund's Blood Crimson Globe, Bastians, Columbia.

(Add 8 cents per lb. if sent by mail.)

Large packets of each sort, 5 c. each; ro pkts. of one or assorted varieties sent postpaid for $40 \mathrm{c}$.

Ounce packets of each sort, Ioc. each; Io oz. of one or assorted varieties sent postpaid for $70 c$.

Crosby's Egyptian. Standard early bunch: ing ............................................................ Dirigo. A foreign beet, but very desirable........ Crimson Globe. One of the finest early ............

Detroit Dark Red Turnip. A main crop sort Extra Early Dark Red Egyptian. Flat and very early....

New Columbia.

1/4 1b. 1b. $51 \mathrm{lb}, 10 t \mathrm{~s}$

Eclipse. Nearly round dark red

Bastian's Early Blood Turnip. Sweet, light ringed.

Lentz Extra Early Turnip. Very sweet and Early Blood Turnip. Standard popular Early Blood Turnip. Standard popular Dewing's Improved. Excellent standard Arlington or Favorite. Popular in Boston

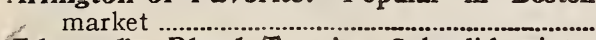
Edmund's Blood Turnig. Splendid winter Dark Stinson. Popular Philadelphia sort........ Dark Stinson. Popular Philadelphia sort......
Long Smooth Blood. Very dark late winter sort .

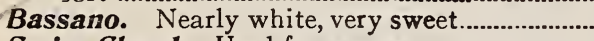
Swiss Chard. Used for greens.

\begin{tabular}{rrr}
\hline .20 & $\$ .65$ & $\$ .50$ \\
.25 & .65 & .50 \\
.25 & .65 & .60 \\
.20 & .60 & .40 \\
.20 & .50 & .45 \\
.25 & .60 & .50 \\
.20 & .50 & .45 \\
.15 & .50 & .40 \\
.13 & .50 & .45 \\
.15 & .50 & .40 \\
.15 & .50 & .40 \\
.15 & .50 & .40 \\
.15 & .50 & .40 \\
.15 & .50 & .40 \\
& & \\
.15 & .50 & .40 \\
.15 & .50 & .40 \\
.15 & .50 & .40 \\
.50
\end{tabular}

Fifty pound lots of one or assorted varieties @ 5c.per $1 \mathrm{~b}$. less than above prices.

Your seeds have always been very good. Every seed seems to grow and produce good crops, particularly parsnip, onion, turnip and beet.

Echo Lake Farm, Interlaken, Mass.

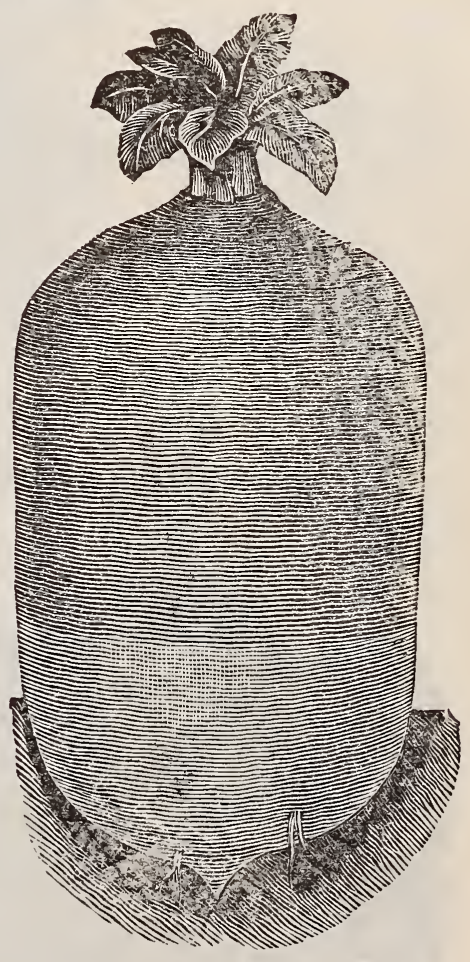

Golden Tankard Mangel Wurzel.

\section{SUGAR BEETS AND MANGEL WURZEL.}

(Add 8 cents per lb. if sent by mail.)

We offer following standard sorts of Mangel Wurzel seeds, all pure and true to name, at a uniform price as follows: per oz., 5c.; per lb., 30c.; 5 lb. lots, $25 \mathrm{c}$.; $20 \mathrm{lbs}$. or over, $20 \mathrm{c}$.
Mammoth Long Red,
Golden Tankard,
White French Sugar,
Norbitan Giant, Gate Post,
Yellow Globe,
Giant Yellow Intermediate, Lane's Imperial White Sugar.

The seeds that I have had from your firm have been perfectly satisfactory, true to name, and sure to frow.

H. A. Felton, Orange, Mass. 


\section{THE CABBAGE.}

With the exception of Danish Ball Head and Early Winningstadt all our Cabbage seed is Long Island grown, and from the choicest strains. Such seeds cost 2 or 3 times as much to produce as the imported seed, but our former customers keenly appreciate our high-grade cabbage seed.

Rollin, Mich., May I, I 905. Enclosed find $\mathrm{M} \mathrm{O}$. for $\$$ I.54 for $\frac{1}{2} \mathrm{lb}$. Danish Ball Head cabbage seed. Last year I ordered of another firm and got a mixed lot of seed which lost me money; am trying several firms this year. Shall tie to the best.

J. M. B.

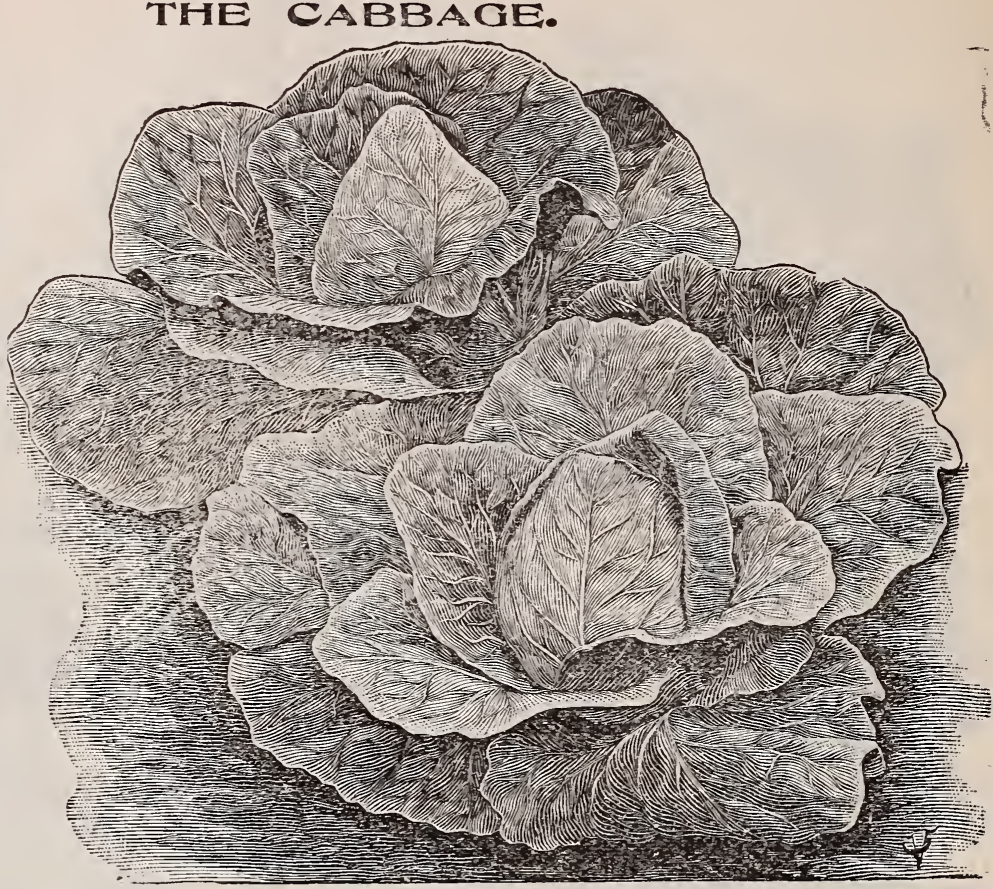

Large, or Charleston Wakefield.

Ro!lin, Mich., Nov. Io, I905.

Your Danish Ball Head cabbage seed was the best that I purchased this year. J. M. B.

Above testimonial meant something to that planter of cabbage seed.

Pkts of each sort, 5c.; ro plts. for 40c., postpaid.

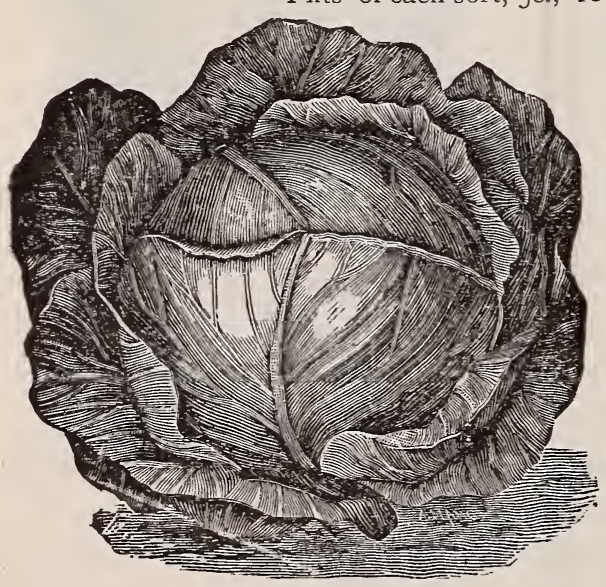

All Head Early.

- The standard early fat summer sort.
All Head Early. The greatest of all early flat Summer sorts............. \$.25 \$1.00 \$3.50

Early Jersey Wakefield. Market gardeners' strain ...................

Large or Charleston Wakefield. Superb strain.

Early Spring Cabbage. Earliest flat head sort................................. All Head Early. One of the standards ................................
Early Winningstadt. Conical Early Winningstadt. Conical Hencerson's Early Summer. Mid-summer sort........................... Henderson's Succession. Mammoth size heads......................... AlI Seasons. Hard heads, medium size .................................... Fottler's Improved Brunswick. One of best winter sorts................ Burpee's Sure Head. A sure heading variety.. oz. $\quad 1 / 4 \mathrm{lb}, 1 \mathrm{~b}$. $.25 \quad .75 \quad 3.00$ .25 I OO 3.50 $\begin{array}{lll}.25 & 1.30 & 4.50\end{array}$ $\begin{array}{lll}.25 & 1.00 \quad 3.50\end{array}$ $\begin{array}{lll}.15 & .50 & 1.75\end{array}$ $\begin{array}{lll}.25 & .75 & 2.50\end{array}$ $\begin{array}{lll}.25 & .75 & 2.30\end{array}$ $\begin{array}{lll}.25 & .75 & 2.50\end{array}$ $\begin{array}{lll}.25 & .75 & 2.50\end{array}$ $\begin{array}{lll}.25 & .75 & 2.50\end{array}$ 


\section{Cabkage - continused.}

oz. $\quad 1 / 41 \mathrm{~b}, \quad 1 \mathrm{~b}$

Stone Mason (Warren's). Standard late............................................................................ $\quad .25 \quad .75 \quad 2.50$

Large American Drumhead. Rig Cropper................................................................... $\quad .25 \quad .60 \quad 2.00$

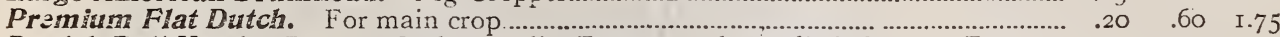

Danish Ball Head. Cannon Bail or Solid Emperor; also/called German Export.

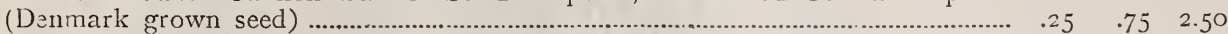

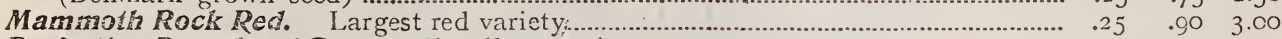

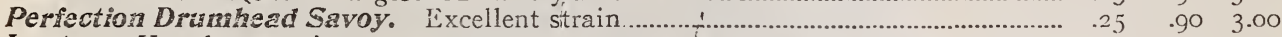

Lupîn. Very large main crop sort

CABBAGE PLANTS. STRONGMARDENED OFF PIANTS.

Selected Jersey Wakefield at $\$ 500$ per $I, 000$ Tarly Summer at $\$ 500$ per 1,000

I.arge or Charleston Wakefield at 500 per 1,000 Burpee's All Head Early, 5.00 per 1,0uo READY ABOIJT APRIL 10th TO 25th.

Write for prices for plants for setting May istrand later. We can supply the leading varieties at any date wanted. prices.

Tomato, Cauliflower, Pepper, Celery, Egg Plantfand Lettuce p!ants in their season. Write for

BRUSSEL SRROUTS.

Sow the same as cabbage through May and transplant in July. Improved Dwarf. Price per plit., 5c ; n7, I5c.

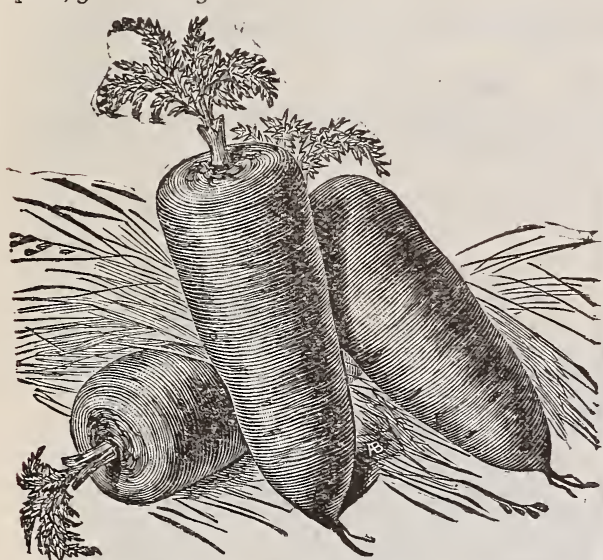

Chantenay, One of best for Bunching.
CARROTS.

Flushing, L. I., Dec. 16.

S. D. Woodruff \& Sons, Gentlemen:-I wish you to book me for thirty pounds of your Half Long Danvers Carrots, same as I had last year. I bought of three other leading seedsmen last year but your seed grew the best crop of carrots. All the different lots of seed were sowed side by side, and given equal chance, but in every case your seed grew the finest crop.

Very truly yours,

H. D. Lott.

What Mr. Lott says of our carrot seed isponly a sample of the many testimonia's we receive from our carrot seed qustomers. If you are looking for cheap seeds you certainly will not come to us, but if you want the very best that money can buy we can supply you with the true stock. VARIETIES OF CAR?OW'S.

Each per pkt,, 5c; oz., IOc:; $\frac{1}{4} \mathrm{lb}, 20 \mathrm{c}$.

Rubicon Half Long Carrot. This is becoming a popular half ling sort. It is very fixed in shape and a grreat crofpar, excellent also for bunching. Lb., 8oc.

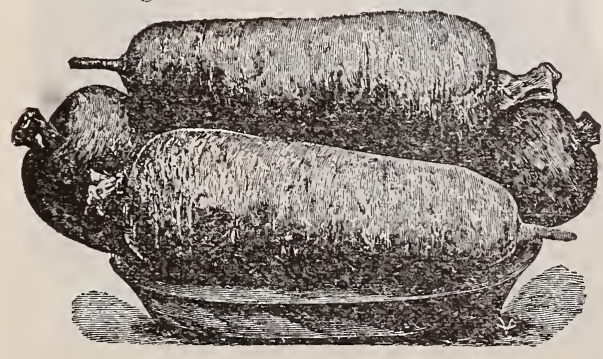

Early Short Horn or Scarlet Horn. Price per 1b., 8 oc.

Chantenay Half Long Scarlet. I.b., 7cc. Saint Vallery or Intermediate Red. Popular trucker's sort. Lb., 7oc.

Half Long Scarlet Nantes. Stump rooted. Lb., 7oc.

Oxheart or Guerande. Great yielder, short and thick. 1.b., 75c.

Danver's limproved, L.b., $7 \mathrm{Oc}$.

Improved Long Orange. Lb., 7oc.

In regard to the sced purchased of you, I have no fault to find with the seed or business principles of your firm.

F. H. Bishop, Ancluver, Mass.

Danver's Improved (Select strain.) Geo. E. Geer, Jewett City, Conn.
G. 
Our Cauliflower is all grown in Denmark and is proven seed, that is one year old and that has been tested and has produced a good crop.

Our stock of Early Snowball Cauliflower is one of the finest ever put out, equal in every way to the orisinator's stock.

Henderson's Early Snowball. Very largely grown for an early crop. It is dwarf and a sure header; heads are large, white aud solid. Pure stock Pkt., I5c.; oz, $\$ 2.50 ; 1 \mathrm{lb} ., \$ 28.00$.

Extra Early $D$ warf Erfiur. One of the earliest varieties. Pkt., I5c; 02., \$3.50; lb., \$20.00.

LeNormand's Short Stem Mannoth. A large stumped variety, and a standard for geacral cultivation. Pkt., IOc.; oz., 6oc.; lb., \$7.00.

Veitch's Autumn Giant. Standard sure heading sort. Price per pkt., roc.; oz., 6ac.; 1b., \$7 $\$$.

John L. Moore, Lowell, Mass., writes under date of Nov. I5, 1904, I recommend your Snowball Cauliflower above any I have ever used, and I have tried seed from all the best seed men.

This means something as Mr. Moore is a very careful and experienced grower whose market that of Boston is most critical.

\section{CELERY:}

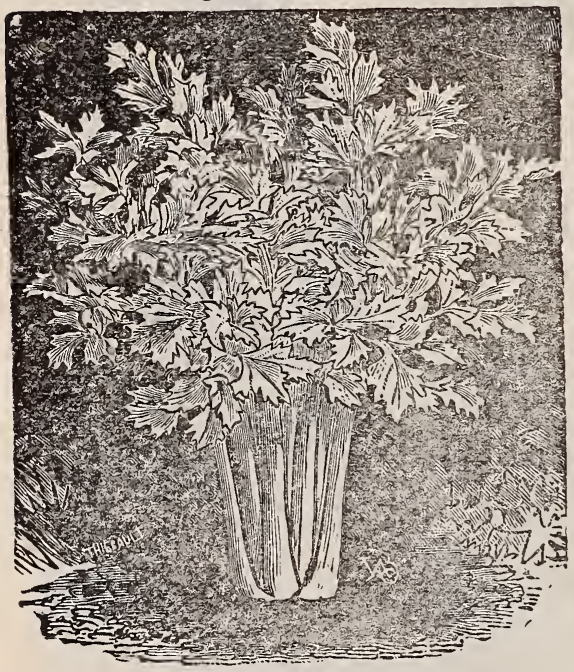

White Plume.

Our strains of White Plume and Golden Self-Blanching Celery are the finest we have seen and we have tried a large number of strains. These items make many friends for us each season. Seed of these varieties is proven stock.

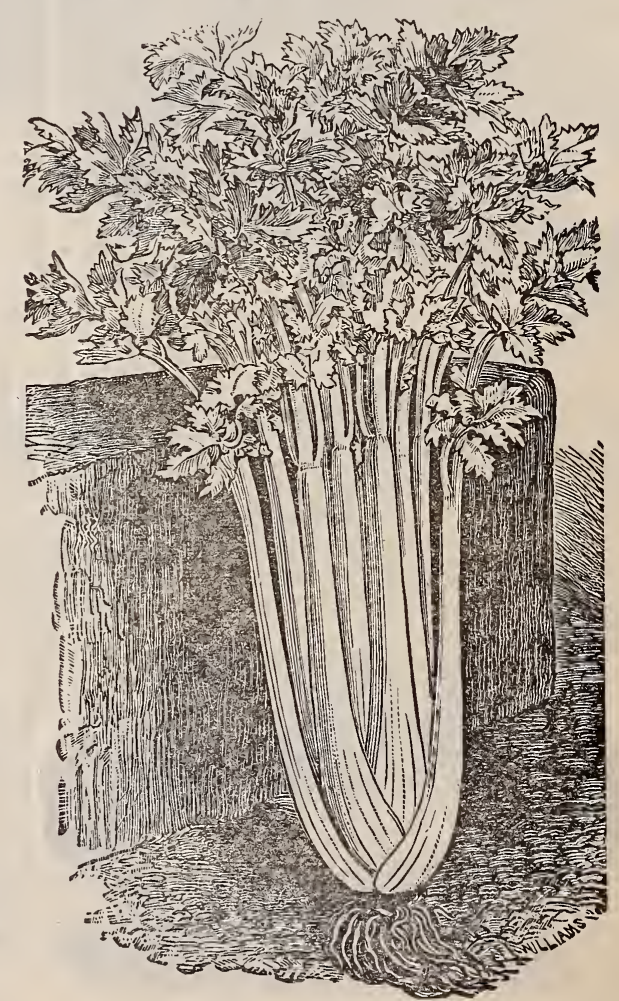

Golden Self.Blanching.

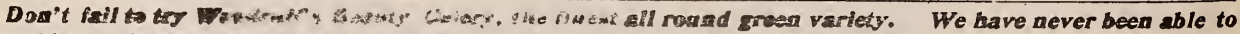

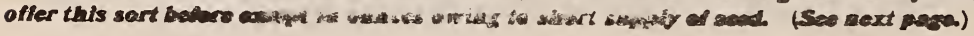




\section{Celery-continued.}

\section{PARIS GOLDEN OR GOLDEN SELF=BLANCHING CELERY.}

Most important and largely used is this sort on account of its fine quality, golden yellow foliage and readiness in bleaching. No one item except Cauliflower and Cabbage depends so vitally on the seed. Our seed of this sort is French grown only and proven seed. Seed grown elsewhere can be purchased at less than one-third the price. Insist on the French grown article of this variety wherever you purchase. Vitality of our seed is good this year, and we hope we have ample supply for our largely growing trade. Pkt., IOc.; Oz., 50c.; $\frac{1}{4} \mathrm{lb}$., \$1.25; 1b., \$4.50; five lbs. at \$4.00 lb.

Woodruff's Beauty. A brand new green Celery of the finest quality. We secured this sort three years ago from the most critical celery grower near New York, and the limited quantity of seed we have been able to produce has made us many good friends. For a medium size solid eașily bleached sort for main crop of finest tender quality and flavor it is unsurpassed. Pkt., Ioc.; oz., foc.; $\frac{1}{4}$ lb., \$1.25; lb., \$3.50.

Our stocks of the following standard sorts of celery are strictly pure and true to name.

Liberal pkts. of each, 5c; ro pkts. for $40 \mathrm{Oc}$., postpaid.

\begin{tabular}{|c|c|c|c|}
\hline Dwarf Golden Heart. & $\begin{array}{l}\text { Per oz. } \\
\$ .25\end{array}$ & $\begin{array}{l}\text { Per } 1 / 41 \mathrm{lb} \\
\$ .50\end{array}$ & $\begin{array}{l}\text { Per } 16 . \\
\text { \$ } 65\end{array}$ \\
\hline Boston Market. Medium sized, good keeper..... & .25 & .50 & I. 75 \\
\hline Giant Golden Heart......... & .25 & .60 & 2.00 \\
\hline Schamacher. Very solid, good keeper.............................................. & .25 & .60 & 1.75 \\
\hline Kalamazoo. Broad ribbed & .25 & .60 & 1.75 \\
\hline Perle le Grande. & .25 & .60 & I. 75 \\
\hline White Plume. Great favorite, extra early sort & .25 & .75 & \\
\hline Pink Plume. The finest of pink sorts & .25 & .75 & 2.50 \\
\hline 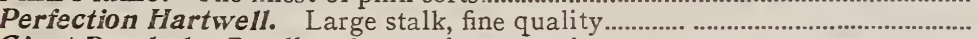 & .25 & .60 & 2.00 \\
\hline Giant Paschal. Excellent keeper, immense size & .25 & .60 & 2.00 \\
\hline 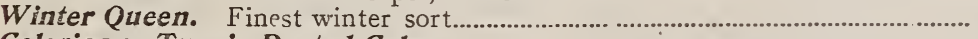 & .25 & .60 & 2.00 \\
\hline $\begin{array}{l}\text { Celeriac or Turnip Rooted Celery } \\
\text { Smallage or Cutting Celery. Used for bunching in soup bunches, very }\end{array}$ & .10 & $\cdot 35$ & \\
\hline lery. Old s & .15 & & \\
\hline
\end{tabular}

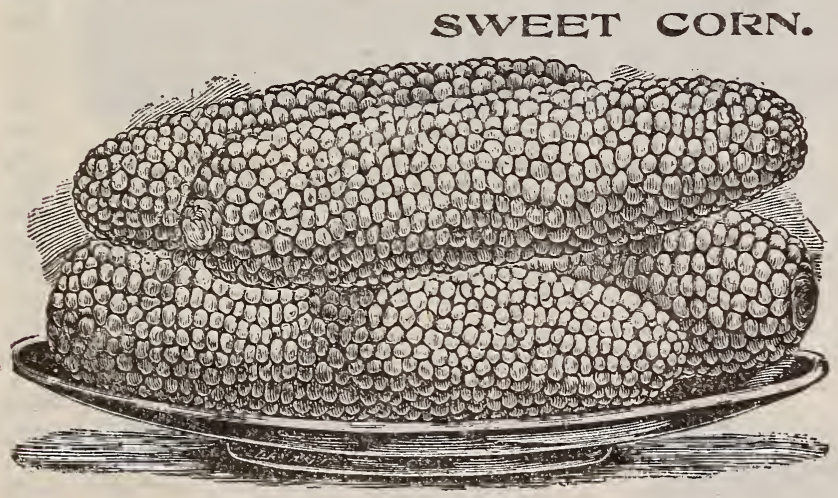

Country Gentleman.

Real merit wins.

We pity a man without a country.

We pity a man without pride.

We have both.

We are proud that it fell to our lot to put out Country Gentleman and Long Island Beauty Corn and Ensign Bagley Potatoes in the best country the sun shines on.

Any novelty of "real merit" helps the buyer and the seller alike. Helps the buyer in profits and the seller in both reputation and profits.

We believe we have the repu-

"The corn that made Orange famous"

(because it. originated with us.) tation of sending out the best Sweet Corn Seed on earth, and we know we can protect our reputation this year for our Sweet Corn seed is better than ever. We have lots of it and at low prices. We supply choice selected ears when ordered. (They cost a trille more but are better.) We reserve the right to ship shelled corn in place of ears when our ear corn has all been shelled. Try us on Corn seed, we know we can please you. We can supply you a pint or a carload.

Long Island Beauty. We put out this new main crop sort last season with more complimentary results than any one novelty last season. It is a large eared medium to late sort, ears about size of late Mammoth, of the finest quality. It remains in edible state longer than any variety we have ever seen. Plkt., IOc.; qt., 20c.; pk., \$1.00; bu., \$3.50; per Ioo selected ears, \$3.50.

Country Gentleman. This well known superior sort needs no description. Originated by us in I892, it has become a standard for quality and productiveness. Our constant selection makes our stock unsurpassed. Pkt., Ioc.; qt., 20c.; peck, 90c ; bu., \$3.00; per I00 selected ears, \$2.75. 


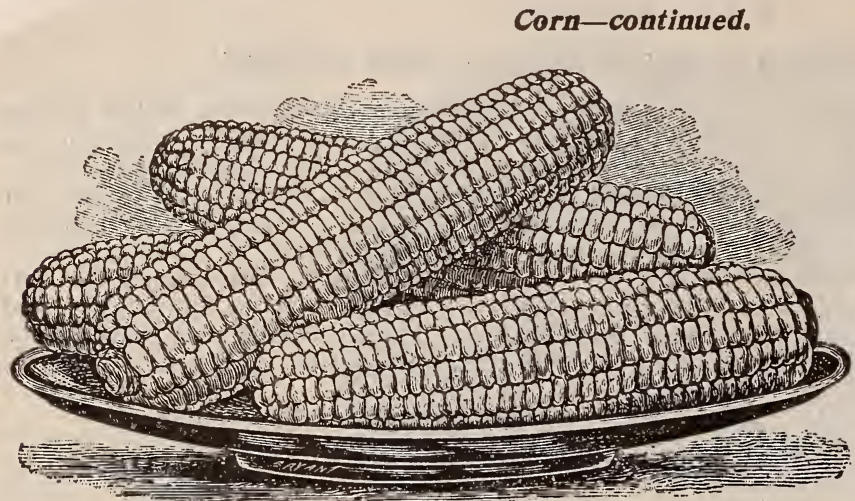

Golden Bantam. A very hardy extra early sort, very sweet. Per doz. ears, 35c.; qt., 20c.; pk., \$1.0o; bu., \$3.50.

Early Sheffield. A cross between Extra Early Adams and Early Cory. Very hardy and early. Prices same as for Golden Bantam.

Space prevents our describing in detail all the following sorts, all of which can be depended on as pure and true and strong vitality.

\section{Long Island Beauty.}

(Add 10 cts. per qt. if sent by mail.)

All sorts 5c. pkt.; IOc., pt.;

The sweetest large eared, most salable main crop sort. I5c., qt.; 8oc., peck.

Early Premo. A fine white extra early

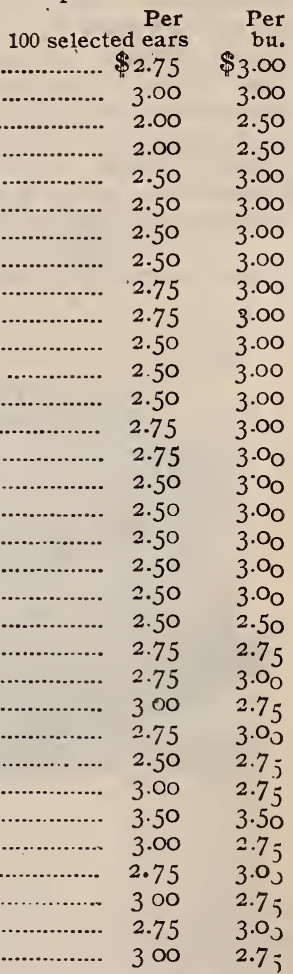

Moonarchie. A variety popular in New Jersey

Large Early Adams or Burlington.

- Extra Early Adams

WFirst of AlI. Resembles Cory, but earlier.

- Early Fordhook. Extra early, large ears, pure white

-Burbank's Early Maine. Fine quality, extra early..

- Extra Early Cory. The standard early sort..

- Early Champion. The largest eared 2nd early.

Metropolitan. New, large eared, 2nd early.

-White Cob Cory. Standard sort.

- Mammoth White Cob Cory.

- Shaker's Large Early. Popular, very sweet...

- Cosmopolitan. Popular 2nd early.

Melrose. Large eared early.

- Early Minnesota.

- Black Mexican. Deliciously sweet.

- Stabler's Early.

Crosby's Early. True strain

- Moore's Early Concord.

- Perry's Hybrid.

Early Evergreen

- Kendall's Early Giant.

- Early Mammoth

- Old Colony.

- Potter's Excelsior or Squantum.

nickox Improved.

- Long Island Beauty.

-Stowell's Evergreen.

- New White Evergreen.

- Roslyn Hybrid.

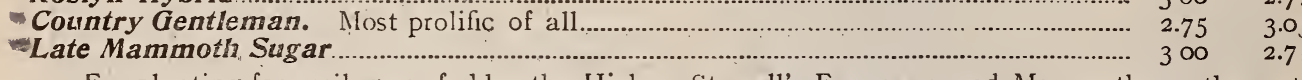

For planting for ensilage or fodder the Hickox, Stowell's Evergreen and $\mathrm{Ma}: \mathrm{m}$ th are the sort most desirab.e. We would advise our friends to buy those of first quality. Writ : fui prices on large lots, 5 bu. or more, either of these, sorts at $\$ 2.50$ per bu.

Metropolitan Sweet Corn seed purchased fro.n you was number one. every seed grew. Irving R. Graves, Northampton, Mass.

The seeds I have purchased from you this season have given entire satisfaction. $\mathrm{n}$ fact are the best I ever bought, and I have bought from the best firms for several years.

P. F. Stillings, Iondon, Ky. 


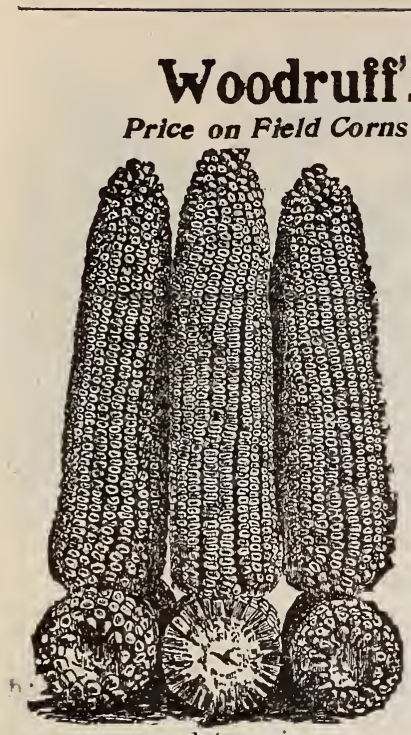

Improved Leaming.

\section{Corn-continued.}

\section{Field and Ensilage Corns.}

The quality of our field corns is extra nice this season. We are prepared to supply 50 to $100 \mathrm{bu}$. of a variety at closest possible prices.

Early Eight=Rowed Yeliow Carada, (very early yel'ow flint). Per Ioo selected ears, \$1.25; qt., 10c.; pk., 50c.; bu, \$1.40.

Longfellow. Standard large yielding yellow flint. Per Ioo se'ected ears, \$1.50; qt., Ioc.; pk., joc.; bu., \$1.40.

Sanford. Standard large yielding white flint. Per Ioo selected ears, \$1.50; qt., roc.; pk., 40c.; bu., \$1.35.

Pride of the North (early, small cob, yellow dent). Per Ioo selected ears, \$I 50; qt., roc.; pk, 50c.; bu., \$I.40.

Early Mastodion. Standard ensilage and main crop, yellow dent. Per Ioo selected ears, \$I.50; qt., Ioc.; pk., 50c.; bu., \$1.30.

Improved Leaming. Deep kernel, great yielder, yellow dent. Per roo selected ears, \$1.50; qt, Ioc.; pk., 50c.; bu., \$I 30

We can supply all other standard sorts field corns at $50 \mathrm{oc}$. per pk.; $\$ 1.40$ per bu.; or 5 bu. or over at \$1.25 per bu.

We will sell 5 bushel lots or over of the above varieties, either one or assorted, at $\$ 1.25$ per bushel, F. O. B. here; 2 bushel bags, I 5 c. each extra.

White Southern Ensilage or Sheep Tooth. Qt., Ioc.; peck, 25c.; bu., \$1.15; 5 bu. lots at \$ I oo per bushel.

Red Cob Ensilage. The standard Silo Corn. Peck, 35c.; bu., \$I.I5; 5 bu. lots at \$1.00; 25 bu. or over at goc. per bu. net cash F. O. B. here; bags I5c. each.

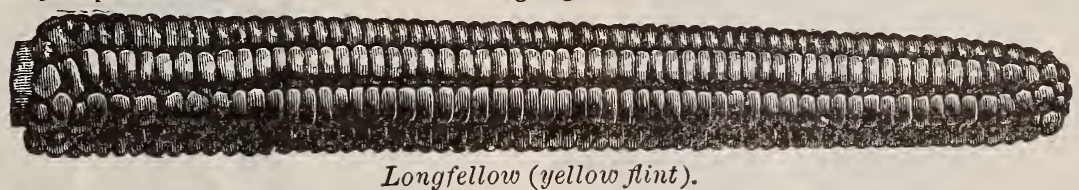

SWEET FODDER CORN.

We can offer a choice lot of Sweet Corn, all large growing varieties, and those who buy a quantity for ensilage generally prefer the Sweet Corn to a field variety. Price per bu., $\$ 1.25 ; 5$ bu. or more at $\$ 1.15$ per bu. You will find this a nice sample and the price is very low.

WHITE RICE POP CORN.

The best sort for popping. Pt., Ioc.; qt., I5c.; pk., 70c.; per lb. on ear, $5 \mathrm{c}$.

Bear in mind that we are extensive dealers in Corn of all kiscis and will be glad to quote special prices on large lots.

\section{$\checkmark$ CUCUMBERS.}

We are pleased to report that a very agreeable change in weather conditions the past year has resu!ted in excellent crops of cucumber seed and we are enabled to quote normal prices. Stocks are very fine and we have ample quantities for all demands.

Peerless or Long White Spine: We have an unsurpassed strain of Peerless White Spine. Pkt, 5c.; uz., IOc.; $\frac{1}{4}$ lb., 20c.; lb., 65 c.

Cumberland Cacumber. One of the best pickling varieties lnown; very thickly set with fare spines, straight and symmetrial, affne-slicing sort, also very shy seeder. Plst, 5c; az., roc; $\frac{1}{4}$ lb., 25c; lb., 70c.

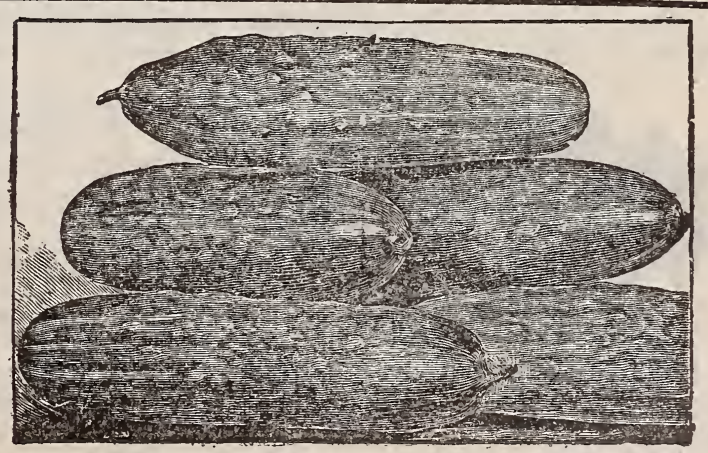

Peerless or Long White Spine. 


\section{Cucumbers-continued.}

Liberal pkts. of all varieties, 5c. each; Io pkts., 40c., postpaid.

Per oz., IOc.; Io oz. plits. for 75 c., postpaid, either of one or assorted varieties.

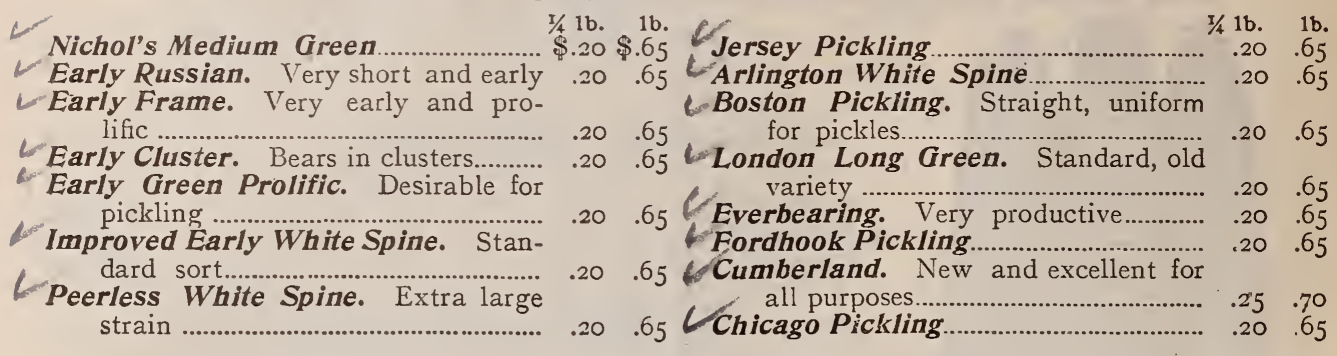

\section{CORN SALAD.}

Large Seeded. Large leaved, the best variety. Price per pkt., 5c.; oz., Ioc.; lb., 6oc.

\section{CRESS OR PEPPERGRASS.}

Price per pkt., 5c.; oz., IOc.; $\frac{1}{4}$ lb., I5c.; lb., $40 \mathrm{Oc}$.

\section{DANDELION.}

The Dandelion resembles Endive, and affords one of the earliest as well as one of the best and most healthy Spring greens.

Improved Large Leaf. Price per pkt., Ioc.; oz., 35c.; $\frac{1}{4}$ lb., \$r.25; 1b., \$4.00.

Common Cultivated. Pkt., 5c.; oz., 20c.; $\frac{1}{4}$ lb., 75 c.; lb., \$2.50.

\section{EGG PLANT.}

New York Improved Large Purple Spineless. The leading market variety, of large size, skin deep purple, smooth, free of thorns, flesh white, of excellent quality, very productive. Price per pkt., $5 \mathrm{c}$.; oz., 40c.; $\frac{1}{4}$ lb., \$1.25; 1b., \$4.00.

Black Beauty. Earliest and best large fruited sort. Pkt., 5c.; oz., 45c.; $\frac{1}{4}$ lb., \$1.25; lb., \$4.00.

\section{ENDIVE (Escarolle.)}

Large Green Curled. A hardy variety, easily blanched Price per pkt., 5c.; oz., Ioc; $\frac{1}{4}$ lb., 30c.; lb., \$r.oo.

Broad Leaved Batavian. Large leaves, long and broad Price per pkt., $5 \mathrm{C}$; oz., I5c.; $\frac{1}{4} \mathrm{lb}, 30 \mathrm{c}$.; lb., \$1.00.

Giant Fringed or Oyster. Pkt., 5c.; oz., I5c.; $\frac{1}{4}$ lb., 30c.: lb., \$1.00.

\section{KALE OR BORECOLE.}

Dwarf Green Curled Scotch. A very hardy variety. Sow ear!y in June and transp ant like cabbage in July. Price per pkt., 5 c.; oz., Ioc.; $\frac{1}{4}$ lb., 30c.; lb , \$1.oo.

\section{Dwarf German Sirouts or improved Early Dwarf Siberian} Kale. A very heavy cropper, and a great favorite in this locality.

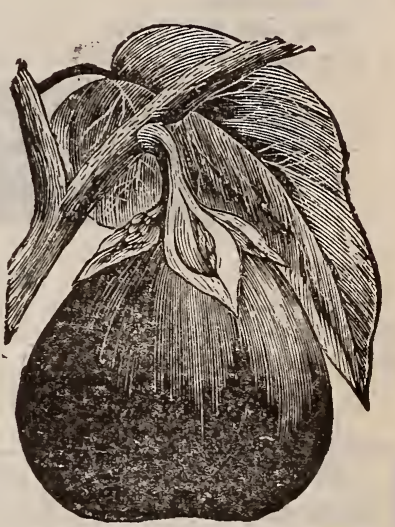

Nevo York Improved Egg Plant-Spineless.

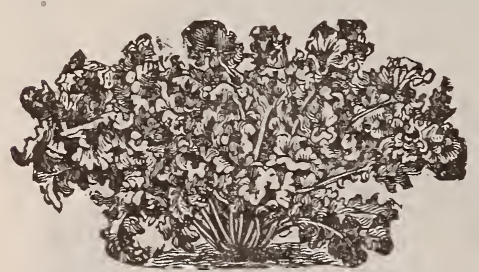

Improved Dwarj Siberian Kale.

Sow in August in rows $I_{5}$ inches apart and harvest next April or May.' Price per pkt., 5c.; oz., Ioc.; $\frac{1}{4}$ lb., I5c.; lb., $50 c$.

I have used your seeds for past six years. I consider them first class and true to name. W. J. M., Pittstown, N. Y

\section{KOHL KABI OR TURNIP CABBAGE.} (Add 8 cents per $1 b$. if sent by mail.)

Early White Vienna. Flesh whire and tender; in best condition for table use when about three cr four inches in diameter. Price per plit., 5 c.; oz., I5c.; $\frac{1}{4}$ lb., 55c.; lb., \$2.00.

Early Purple Vienna. An excellent sort, largely grown for tab'e use. Price per plit., 5c.; oz., I 5 c.; $\frac{1}{4}$ lb., 5oc.; lb., \$I.75. 


\section{GOURDS.}

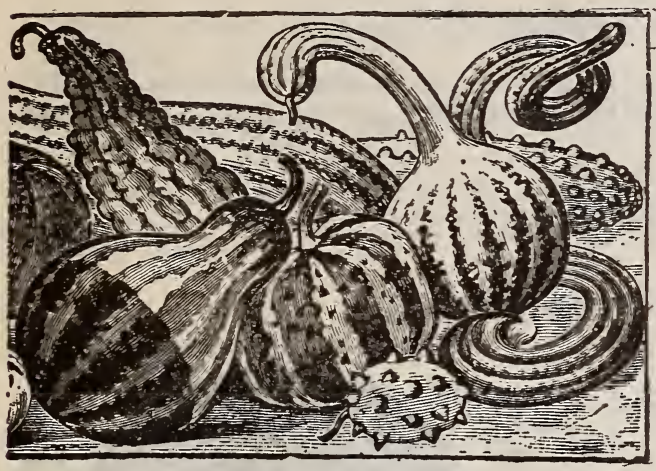

Gourds.

Price of each 5c., pkt.; 25c., oz.

Nest Ezg. A capital nest egg.

Sugar Trough. Valuable when dried fot buckets, cans, etc.

Dipper. Its name indicates its use.

Apple-Shaped.

Pear=Shaped.

\section{LEEK.}

American Flag. A large standard variety. Price per plkt., Jc.; oz., I5c.; $\frac{1}{4}$ lb., 40 c.; lb., \$1.00.

Large Mussellurg or Carentan. The largest in cultivation. Price per pkt., 5c.; oz, I5c.; $\frac{1}{4}$ lb., 50c.; lb., \$1.50.

\section{LETTUCE.}

Culture. Lettuce, the most useful of all salads, is easy of culture, being free from all diseases and insects. It requires rich, moist soil, clean cultivation and plenty of water. This will give the quick growth on which depends its appearance, tenderness and flavor. For early Spring use, sow in a seed bed in September or October, and protect through the Winter with cold frames. (Add 8 cents per lb. if sent by mail.)

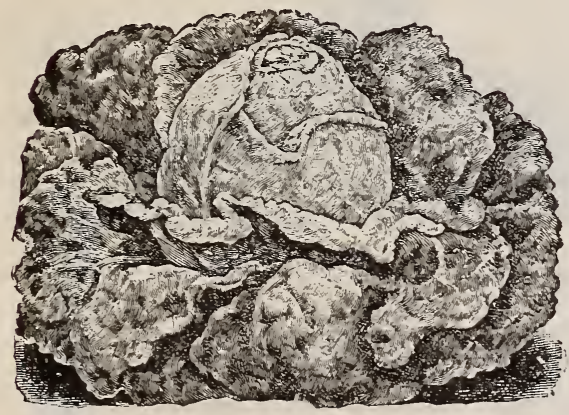

Big Boston.

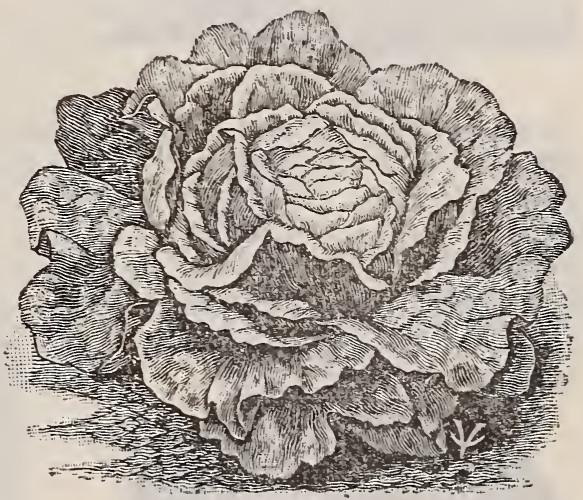

Salamander.

Pkts. each sort, 5c.; oz., I5c.; $\frac{1}{4}$ lb., $40 \mathrm{c}$.

Big Boston. Uniformly large heading sort. Per lb., \$ i oo.

Early Curled Simpson. Curled, loose head. Per lb., \$ r.oo.

Black Seeded Simpson. Per lb., \$1.0o.

Early Curled Silesian. Per lb., \$ r.oo.

Unrivaled. Large head; green without, white within. Per lb., \$1.00.

Boston Market or White Seeded Ten= nis Ball. The standard forcing early variety

Black Seeded Tennis Ball.

Deacon. Forms compact, solid heads...

Hanson. Heads large, green outside, white within. Our stock is very fine....

New York Cabbage or Wonderful. Large head, very crisp.

Salamander. Probably the best compact head for outcloor use. Will with. stand Summer heat without running to seed.
Per 1b.

Early Prize Head. Large, loose head bronze leaves...........................................

Per $1 b$.

\begin{tabular}{|c|c|}
\hline $\begin{array}{r}\$ 1.00 \\
1.00\end{array}$ & $\begin{array}{c}\text { Mammoth Black Seeded Butter or } \\
\text { Mammoth Salamander }\end{array}$ \\
\hline 1.00 & Market Gardener's Private Stock. \\
\hline 1.00 & $\begin{array}{l}\text { This, for an all around lettuce, is a } \\
\text { great favorite with Long Island } \\
\text { truckers }\end{array}$ \\
\hline
\end{tabular}

I.OO

1.00

Grand Rapids. Desirab?e for forcing....

Hittinger's Belmont Forcing ................

1.00

1.00

I. 25

I.00 Paris White Cos or Romaine Lettuce , 1.25

"Our stocks of Big Beston, Salamander and Mammoth Black Seeded Butter Lettuce are as ear perfection as it is possible to produce. 


\section{MUSK MELON.}

Liberal packets each sort, 5 c.; oz, Ioc.

We have exercised the greatest care in the growing of our melon seeds, both Musk and Water Melons, and we can recommend our stocks to be of the purest and truest types obtainable. (Add 8 cents per $1 b$. if sent by mail.)

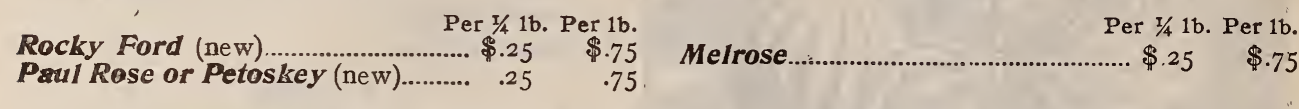

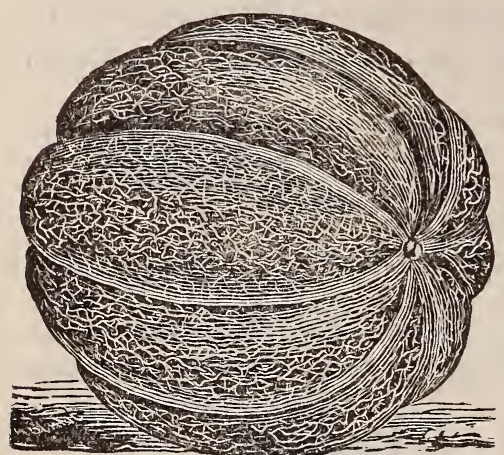

Large Hackensack.

Extra Early Hackensack. Ripens ten days earlier than Large Hackensack; green - fleshed. Per $\frac{1}{4}$ lb., 25c.; lb., $75 \mathrm{c}$

\section{Large}

Hackensack.

Nearly round, green fleshed, large. Per $\frac{1}{4}$ lb, 25c.; 1b., 75c.

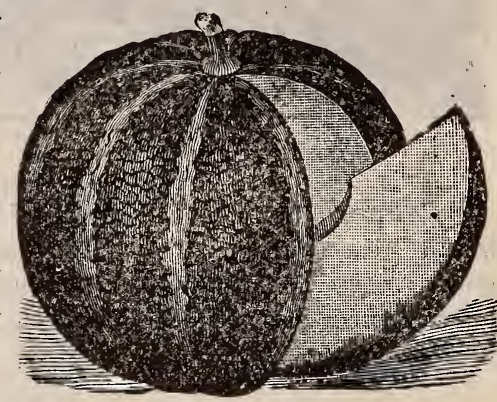

Emerald Gem.

Osage or Miller's Cream. Large, very productive; yellow flesh, favorite market sort........ $\$ .25 \$ \frac{1 \mathrm{~b}}{\$ .70}$ Emerald Gem. ' Most luscious of all; green skin, yellow flesh................................................ . .30 1.00 $\begin{array}{lllll}\text { Prolific Nutmeg. Thick green flesh and skin, medium size and of excellent flavor................ } & .25 & .70\end{array}$ Netted Gem .......................................................................................................................... $\quad .25 \quad .70$ Surprise. Cream colored skin, thick salmon flesh; resembles White Japan, but larger........ $\quad .25 \quad .70$ Early Jenny Lind. Medium to small size; green fteshed, early ................................................. $\quad .25 \quad .70$

\section{WATERMELON.}

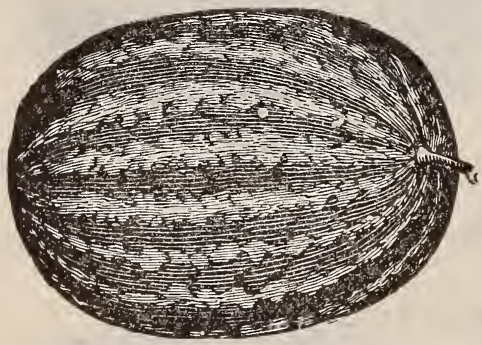

The Dixie.

(Add 8 cents per $1 b$. if sent by mail.)

Liberal packets each sort, $5 \mathrm{c}$; ; oz., roc.

Eden Gem. A new melon, cross between Kolb Gem and Rattlesnake; a great shipper and exceedingly sweet. So great is the demand for this melon in the south, particularly in North and South Carolina, that it has taken the lead over all others as a money maker. Per $\frac{1}{4} \mathrm{lb}$., 25c.; lb., 9oc ; 5 lbs. and over at $75 \mathrm{c} .1 \mathrm{~b}$.

The Dixie. This sort continues to prove a winner, and in this climate gives uniformly satisfactory crops. Per $\frac{1}{4}$ lb., 2oc.; 1b., 75 c.

Hangarian Honey. Nearly globular, very ear!y; rather small, luscious and sweet; good for family use. Per $\frac{1}{4}$ lb., 20c.; 1b., $75 \mathrm{c}$.

Kleckley Sweets. A new oblong melon, one of the sweetest in existence; bright red flesh, white seeded. Per $\frac{1}{4}$ lb., 3oc.; lb., 75c. atrial. 


\section{Watermelons-continued.}

Phinney's Early. White seeded, large early

Per pkt. Per oz. Per $1 / 41 b$. Per $1 b$.

Sweet Heart. A new melon of Western introduction, and becoming a great favorite

$\begin{array}{ccccc}\$ .05 & \$ .10 & \$ .20 & \$ .75 \\ .05 & .10 & .20 & .75 \\ \text { d } & .05 & .10 & .20 & .75 \\ . . & .05 & .10 & .20 & .75 \\ .05 & .10 & .20 & .65 \\ .05 & .05 & .10 & .20 & .65 \\ . .05 & .10 & .25 & .75\end{array}$

Seminole. Early, enormously productive, light gray color, long shape $.05 \quad$ io $20 \quad 75$

Peerless or Ice Cream. (True white seeded). Flavor fine, thin rind oblong shape, dark green skin.

Mammoth Ironclad. Large and heavy cropper............................................. .05

Mountain Sweet. One of the best for general culture................................... . . .

Citron. Used only for preserves

\section{MUSTARD.}

White London. Price per oz., 5c.; $\frac{1}{4}$ lb., 15c.; 1b., 35c.

\section{NASTURTIUM OR INDIAN CRESS.}

Dwarf Mixed. Price per pkt., 5c.; oz., Ioc.; $\frac{1}{4} \mathrm{lb}$., 3oc.; lb., goc.

Tall Mixed. An ornamental climber. Price per pkt., 5c.; oz., Ioc; $\frac{1}{4} \mathrm{lb}$., 3oc.; lb., Eoc.

\section{OKRA OR GUMBO.}

A vegetable in high esteem for soups or stews. Per pkt., 5c.; oz., 1oc.; $\frac{1}{4}$ lb., I 5 c.; lb., 4 or White Velvet. Puds round, smooth and free from seams.

Dwarf Green. Very dwarf and prolific.

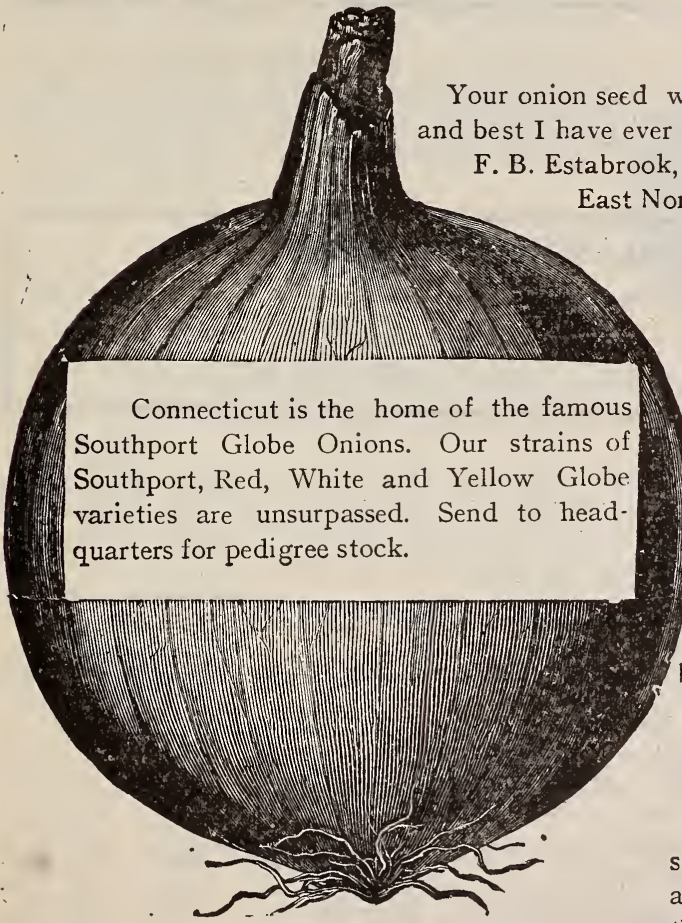

\section{ONIONS.}

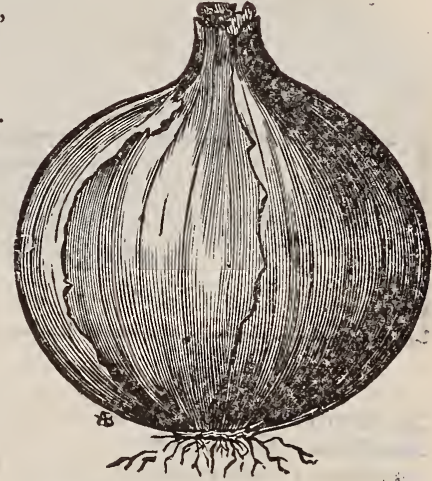

Southport Red Globe.

I am well satisfied with the onion seed I bought of you.

Geo. Geer, Baltic, Conn.

Franklin Co., Mass., Dec. 4. I9O4. Our dealings with your firm have been very satisfactory. Consider your seeds are reliable as any in the market and shall continue to use them.

W. L. Hubbard.

Noble Co., Indiana, Sept. 2, "1905

Yours of Aug. 3ist received and noted. Your terms are quite satisfactory and we accept them. Book order for $1000 \mathrm{lbs}$. onion seed now and we shall probably wish to increase this order later. The finest onions in this locality were grown from your seed this season; all three varieties, Red, White and Yellow Globes.

Onion growers will do well to buy their seed direct from the growers of the seed. Our seed is all thoroughly, tested and will please you as it does hundreds of other critical growers in the country. 


\section{PEDIGREE ONION SEED.}

We use the term PEDIGREE for we believe our seed has gained a pedigree among the largest onion raisers in the east. Critical growers are realizing more and more the error made in buying onion seed because it is CHEAP. Our prices will not and cannot appeal to planters who want CHEAP seed, but the fact of our having orders at this date, Dec. I, I905, booked for thousands of pounds of seed for 1906 planting, orders received many of them unsolicited, speaks in no uncertain terms of the quality of the seed we supply the most critical growers of onions.

We feel justified in claiming for our seed all that can be said about any seed, viz., that it is as GOOD AS CAN POSSIBLY BE PRODUCED. Now the reasons for this claim are these; we grow our onion seed from selected bulbs on our own seed farms. We carefully harvest and cure the seed. We offer it to you direct. The price is as low as we can produce the very best seed. ONCE A TRIAL ORDER ALWAYS A CUSTOMER has always been our motto regarding onion seed.

\section{CAUTION FOR 1906.}

The supply of strictly Pedigree stccks of onion seed this year is less we confidently believe than it has been for I4 years since the numorable short crop of I892. This is especially true of the Southport Globes, Red, White and Yellow and Yellow Globe Danvers varieties. Satisfactory strains of these sorts cannot be sold at anything like the low prices of last year. Beware of cheap prices on onion seed for 1906 sowing.

Cheshire, Mass., Feb. 7.

Dear Sirs:-Last year I sowed your Yellow Globe Danvers Onion seed by the side of seed I bought of a reliable dealer near home. Plants from your seed took the lead, held it all summer, and at harvest time produced more than double the amount of fine onions which the other produced.

I. E. Phelps.

\section{SOUTHPORT GLOBE ONIONS.}

This is the home of the Southport Globe Onions, Red, White and Yellow. Our stocks are simply perfect. The Red, a very dark blood red, no pale red onions in our stock; the White, a pure snow white, and the yellow, a deep orange yellow. Supply of seed very limited.

Southport Yellow Globe.
Southport Red Globe.......

Southport White Globe.

oz.

$\$ .20$

.20

.25

Packets of all sorts, $5 \mathrm{c}$. each.

We offer all of the following sorts of well-known onions, and our stocks of each are the very best obtainable.

Extra Early Red Flat. Extra early dark red flat oz. $\quad 3 / 4$ 1b. 1b. $51 \mathrm{bs}$.

Early Yellow Cracker. Extra early flat, bright yell Large Red Wethersfield. Standard, deep red.. Yellow Danvers Flat. Early, big cropper.

Yellow Globe Danvers.

Ohio or Michigan Yellow Globe.

Yellow Dutch or Strasburg. Used for sets...

Mammoth Prizetaker. American grown.

White Queen or Extra Early Barletta.

White Portural or Silverskin. Standard white fat...................................... .20

Australian Brown. Best keeping variety known

Mammoth Silver King. Immense size....................................................................... . I5

Extra Early Globe, Australian Globe or Golden Globe.

\$.15 $\$ .40 \quad \$ 1.20 \$ 1.10$

$.15 \quad .40$

.15

.15

.15

.15

.15

.15

20

20

.15

$\begin{array}{lll}.40 & \text { I.5O I.40 }\end{array}$

.35 I.IO 1.00

$\begin{array}{lll}.40 & 1.00 \quad .80\end{array}$

$\begin{array}{lll}.50 & \text { I.70 } & \text { I.60 }\end{array}$

$\begin{array}{lll}.50 & \text { I.70 } & \text { I.60 }\end{array}$

$\begin{array}{lll}.35 & .90 \quad .80\end{array}$

.40 . I.5O I.40

$\begin{array}{lll}.50 & \mathrm{I} .75 & \mathrm{I} .50\end{array}$

$\begin{array}{lll}.50 & \mathrm{I} .75 & \mathrm{I} .50\end{array}$

$.35 \quad .90 \quad .80$

$\begin{array}{lll}.40 & \text { I. } 35 & \text { I. } 25\end{array}$

$.40 \quad 1.40 \quad 1.30$

Yellow Globe Danvers. Prices for I906. Per plst., 5c.; oz., I 5c.; $\frac{1}{4}$ lb., 50c; 1b., $\$ 1.70$; 20 lbs. and over at \$I.55 per lb.; 50 lbs. and over at \$I.50 per lb. price.

Do not be tempted to buy onion seed of uncertain quality because it is a few cents less pęr $1 b$. in 


\section{WE GROW ONION SEED BY THE TON}

WE GROW ON OUR OWN SEED FARMS HERE AT ORANGE, CONN., thousands of pounds, YES, several tonS of onion seed annually. We do not claim to grow all of the onion seed we sell, for some varieties are grown in other sections of the world better adapted for their particular types; but growing as we do a very large part of our seed, we have a right to claim that is superior to much of the "cheap" seed on the market.

\section{ONION SEED FOR GROWING ONION SETS.}

The following sorts of onions are used for producing onion sets, and we quote special low prices for these in lots of not less than 50 lbs. of a variety, net cash.

Extra Early Red Flat and Red Wethersfield@ 9oc. lb.

Yellow Flat Danvers and Yellow Strasburg@7 oc. 1b.

White Silverskin, White Portugal and White Queen@\$r.rolb.

\section{SOUTHPORT WHITE GLOBE.}

True seed of this onion can only be produced from carefully selected bulbs. Seed from such bulbs is not plentiful this year, but our customers will, if they order early while our stock lasts, obtain seed from pure white globe-shaped onions. We challenge comparison with any one on our seed of this variety. Price per pkt., 5c.; oz., 25c.; $\frac{1}{4}$ lb., 75 c.; lb., $\$ 2.50$.

One of the expert onion growers in the Southport, Conn., section, wrote under date of Sept. 25, the following:

"The Southport White Globe Onion seed I purchased of you last spring proved satisfactory in every respect. The onions grown from it are as good shape as those grown from my own seed, and the vitality of your seed was much better than my own seed."

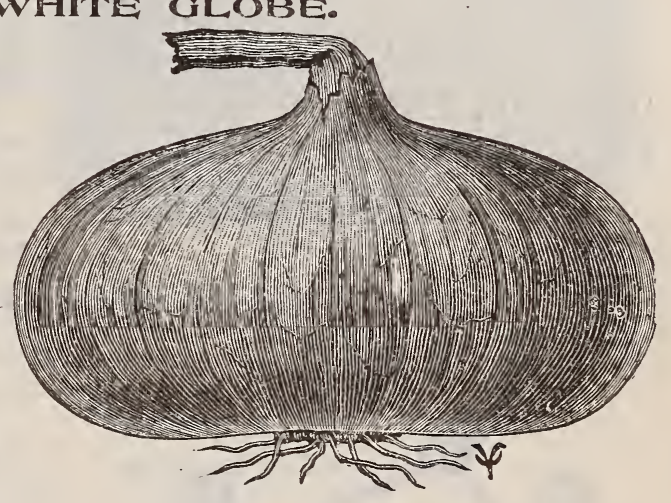

The Early Cracker Onion.

We could print numerous other testimonials regarding our Southport Red liobe and Southport Yellow Globe varieties. Some of the finest crops in the United States grow from our seed.

Our prices are low considering quality of our seed. Give us a trial; we can serve you whether you use I oz. or 500 pounds. We have many planters among our customers who purchase annually from 50 to 200 pounds each.

Our trade on onion seed among the planters of America has increased over 50 per cent. each year for the past four years. The only reason we know for the increase is the fact that our seed has given universal satisfaction and good seeds have made for us many good friends.

\section{ONION SETS}

\section{CHOICE PHILADELPHIA GROWN SETS.}

\section{WE ARE HEADQUARTERS FOR THE EAST.}

No crop the farmer puts in the ground is surer to return a profitable crop than a crop of onion sets. If you set good sound sets and give them good soil and good culture, a fairly good crop is assured.

Markets for past two or three years have been good, and in almost every case crop has been moneymaker.

, We can supply onion sets by the quart, peck, bushel or carload and we wish to say that while the quality of our red and yeliow sets is strictly fine, small, bright and sound, white sets this year are quite a little discolored owing to wet weather at harvest time; and while we believe that our white sets are as nice as anyone has this season and better than many, we want our customers to know that our white sets will not be as pure white and handsome as usual this year. 


\section{Onions-continued. \\ You Will Find Our Onion Sets of Very Choice Quality.}

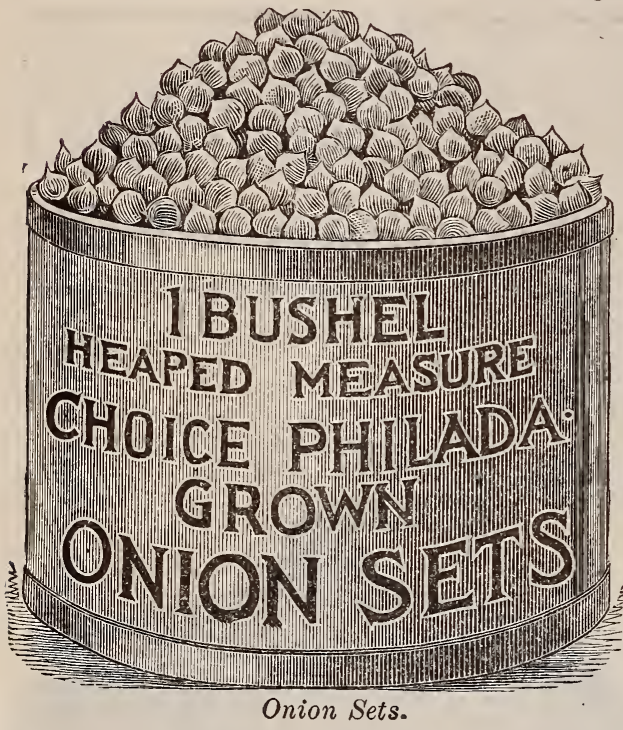

Prices are net and subject to advance, and in all probability will be much higher. Order early.

CHOICE PHILADELPHIA ONION SETS.

Per qt. Per pk. Per bu. 5 bu. 1 ots Yellow Onion Sets.... \$.15 $\begin{array}{llll}\text { \$.7 } & \text { \$2.90 } & \$ 275\end{array}$ $\begin{array}{lllll}\text { Red Onion Sets.......... } & \text {.I5 } & .75 & 2.90 & 2.75\end{array}$ $\begin{array}{lllll}\text { White Onion Sets...... } & .20 & .90 & 3.50 & 3.25\end{array}$ Potato Onion Sets...... . . 5 .90 $3.00 \quad \underline{-1}$ (Add 10 cents per quart if sent by mail.) 25 bu. or over at $25 \mathrm{c}$. per bu. less than above prices.

\section{IMPORTANT.}

WE FILL ALL ACCEPTED ORDERS.

This fact was appreciated by our customers last spring when we were shipping hundreds of bushels of sets that were worth two or three times our catalogue prices. We can supply sets in any quantity from a pint to a carload of each variety, and have them now in storage both at Orange and New York.

Several of our customers reported yields of 500 to $550 \mathrm{bu}$. per acre from onion sets we supplied them -in 1905 .

We grew on our farms last season a crop of onions from onion sets that yielded $6_{4} 0$ bushels per acre.

\section{Two of the Tools Every}

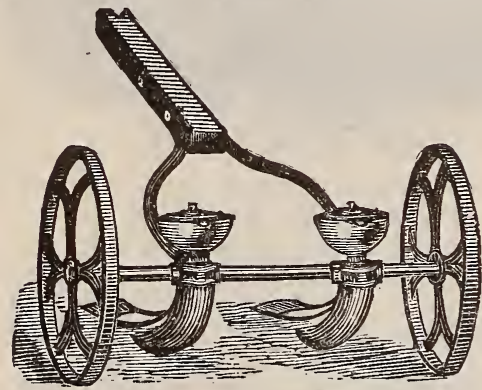

Universal Onion Drill. Onion Grower Should Own

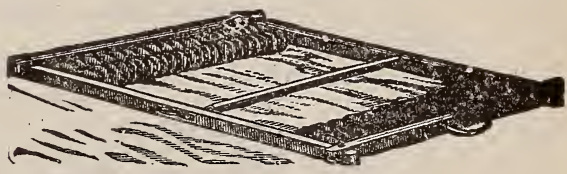

Meeker Smoothing Harrow.

No one who raises one acre or more of onions can afford to be without this tool. It does away entirely with hand-raking the soil. Upon our own farms we would not be without one for three times its cost. Price $\$ 20.50$ or 5 per cent. discount for spot cash.

This is the drill used almost exclusively by onion growers in the Southport, Conn., section, and it is needless to say that it is considered the very best drill in use. It sows with great accuracy two rows at a time, I2 or I $_{4}$ inches apart. Net price, $\$ 7.00$.

I have tried the seeds of almost all the prominent dealers and find that yours do well for me every time, and I recommend others to take yours.

H. F., Plymouth, Conn.

Your seeds gave satisfaction the past season.

J. L. Burke, Syosset, L. I.

\section{PARSLEY.}

One of the finest plants for garnishing; used for flavoring soups, stews and salads. Sow as early as possible in Spring in shallow drills fifteen inches apart, raking the soil fine and level on top. Cover the sced one-third of an inch. The plants appear in from two to six weeks. Succeeds in common garden soil.

Champion Moss Curled. The standard market sort. Our stock of this is extra double curled and one of the finest stocks to be had. Used very extensively on Long Island. Price per pkt., 5c.; oz., Ioc.; $\frac{1}{4}$ lb., 25 c.; lb., 65c.; 5 lbs. at 6oc. per lb.

Fern Leaf. Very fine crimpled leaves. Price per pkt., 5c.; oz., Ioc.; $\frac{1}{4}$ lb., 25c.; 1b., $75 \mathrm{c}$.

Plain Leaf. A very hardy variety. Price per plt., 5c.; oz., 10c.; $\frac{1}{4} 1 \mathrm{lb}, 25 \mathrm{c}$.; $1 \mathrm{~b} ., 75 \mathrm{c}$. 


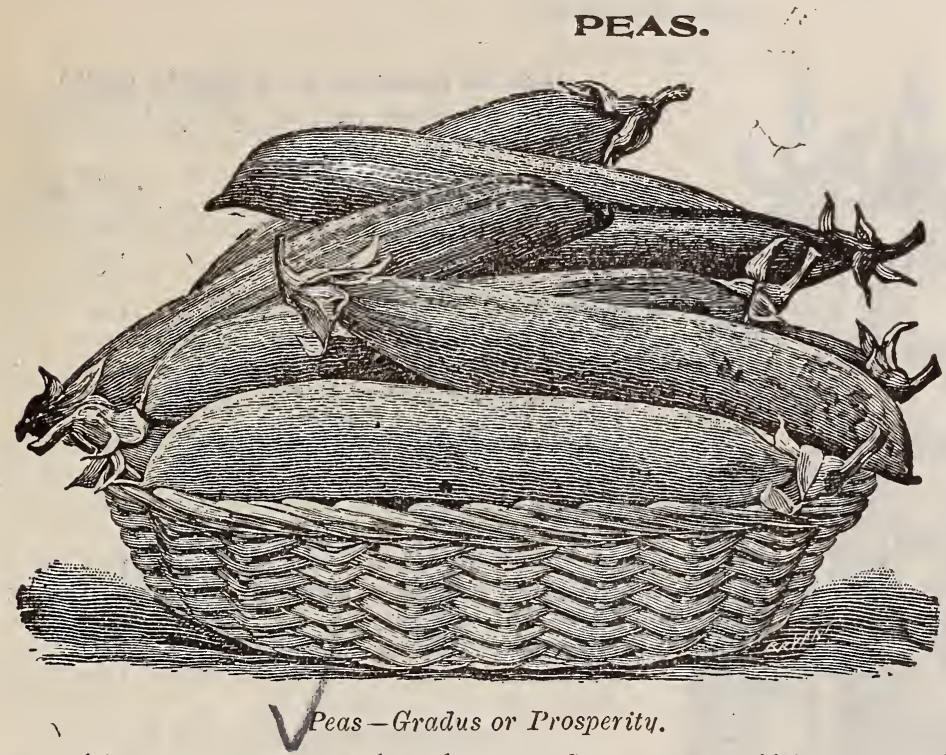

Note our prices on Gradus and Thos. Laxton Peas lower than ever before offered, and our stocks are very superior and fine samples. Try the new pea Ameer; it is a winner.

Gradus. One of the greatest vegetable novelties introduced during recent years. The new pea Thomas Laxton, which seems destined to rival Gradus, is the only sort anywhere near approaching it in size of pod and earliness.

Imagine a wrinkled pea witl a pod very nearly as large as Stratagem or Telephone, and maturing within three or four days as early as Alaska, or any of the other round, extra early sorts, and you will get an idea of exactly what this pea is. Price per pkt., Ioc.; qt., foc.; pk., \$2.00; bu., $\$ 7.75$; ro bushels, $\$ 75.0$ ॥ cash/ no discount.

Thos. Laxton Pea. The growth of this sort is similar to Gradus; pods a trifle darker green, square at the end. Maturés two or three days later than Gradus. Price per pkt., roc.; qt., 30c., pk., \$1.75; bu., \$6.00; ro bushels, $\$ 55$ oo cash, no discount.

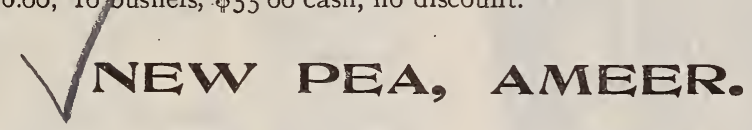

A new pea from England, described by the introducers as follows: "A large podded extra early sort, resembling Alaska. In general appearance the peas and pod, however, are nearly twice as large as Alaska, matures three days later than Alaska.

We have received numerous words of praise for Ameer and strongly recommend it. A very hardy sort; will stand planting much earlier than most other sorts. Per plkt., roc.; qt., 35c.; peck, \$I.75; bu., $\$ 6.00$.

S. D. Woodruff \& Sons, 82 Dey St., New York.

Jamaica, L. I., Jan. 2d, I905.

Gentlemen:-

The Southport Yellow Globe Onion seed we purchased of you last Spring produced a crop yielding over eleven hundred bushels of Onions per acre. Book us for $25 \mathrm{lbs}$. for this Spring sowing.

We were also well pleased with the Ensign Bagley Potato from which we harvested and sold four hundred bushels of Potatoes per acre. We shall need fifty barrels for planting this Spring.

Very truly yours,

W. and J. R. VANSICKLEN.

The Van Sicklen Brothers are two of the largest and most successful truckers on Long Island.

All our Peas are grown in the far North, are carefully rogued in the field, are handpicked samples, free from bugs or vermin of any kind.

Remember Woodruff's Seed Potatoes are grown from their own special selected seed and pure and true to anae. 


\section{Peas-continued.}

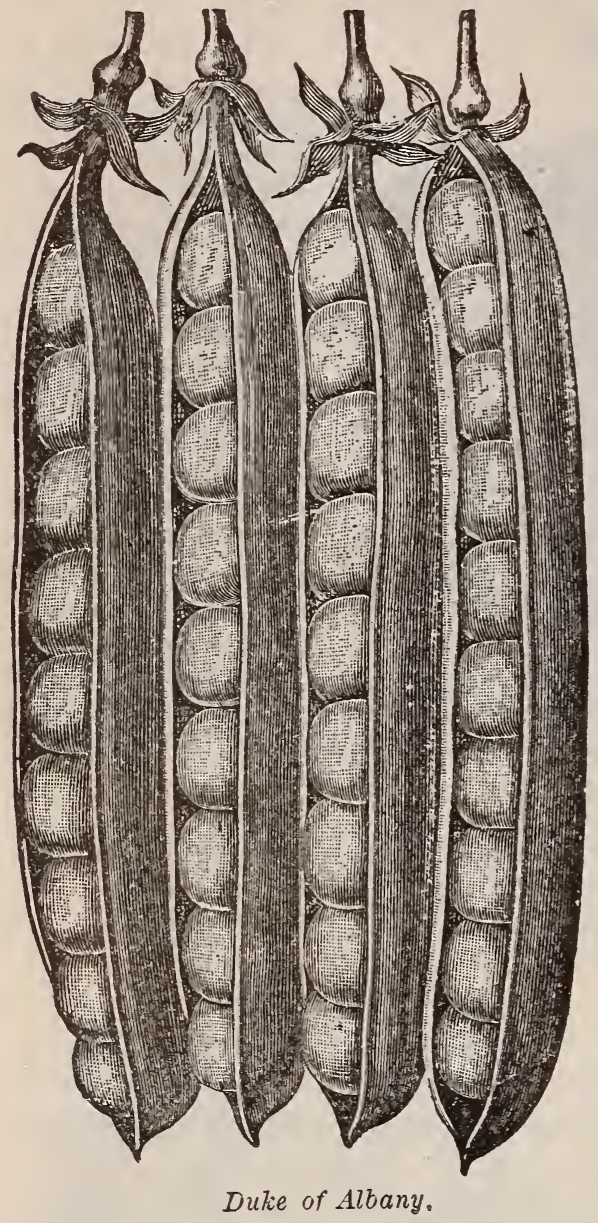

(Add 15 cents per qt. if sent by mail.)

Large packets, IOc.; 20c. per qt. for all sorts in following list.

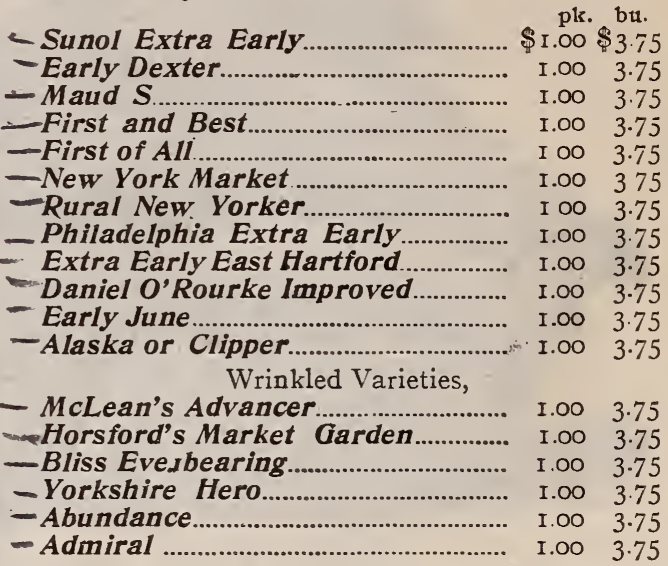

Io bu. or more of any of above at $\$ 3.25$ bu.

Large packets, Ioc.; $25 \mathrm{c}$. per qt. for all sorts in following list.

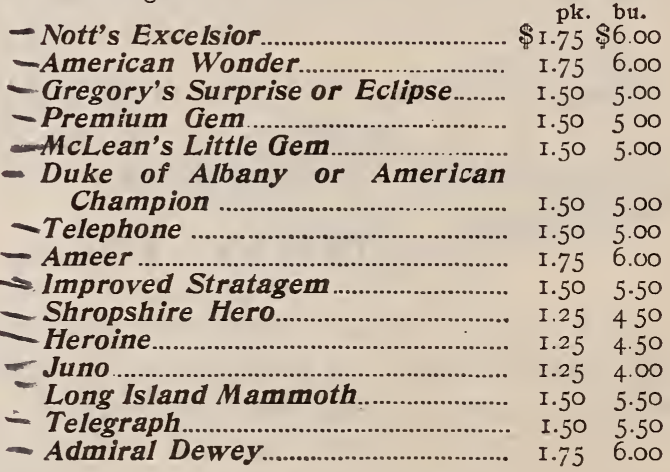

Champion of England. One of the best; height 5 feet.

pkt. qt. pk. bu. $\$ .05 \$ .20 \$ .80 \$ 3.00$

- Marrowfat Black Eyed. A popular standard sort.

$\begin{array}{llll}.05 & \text {.10 } & .75 & 2.75\end{array}$

White Canada Field. Crop extremely short.

$\begin{array}{lll}.15 & .50 & 1.60\end{array}$

Barley and peas are also being sown extensively for a fodder crop. Price of barley, \$r.ro per bu.; 5 bu. and over at $\$ 1.00$ bu., net price; 2 bu. bags, 20c. each extra.

Northampton, Mass., June 22, 1905.

Gentlemen-I am perfectly satisfied with all the seeds I have had from you and I am more than satisfied with results from Nitro Culture. I put it on an acre of peas and it was the best piece of peas I have had for 12 years. Shall buy more next year.

Chas. L. Sanderson.

See Page 1 for prices of Nitro Culture. This bacteria appears to have shown remarkable results in many uses. It is expected much greater results will follow. 


\section{PEPPER.}

Chinese Giant. This is as name implies a "Giant" among peppers, being twice the size of such well-known sorts as Ruby King and Sweet Mountain. They are very firm and hard and mild, in fact quite sweet. They are commonly 4 to 5 inch in breadth and about the same length. Not as "immensely productive" as some seedmen claim. Pkts., Ioc.; oz., 30c.; $\frac{1}{4}$ lb., \$I.20; lb., \$4.00.

\section{PEPPERS.}

Pkt. of each variety, 5c.; Io pkts. for 4 oc., postpaid.

Sweet Mountain. Grows to large size; shaped somewhat like the Bell, but much larger; much used for pickling. The standard market variety. Per oz., 25 c.; $\frac{1}{4}$ lb., 75 c.; 1b., $\$ 2.50$.

Ruby King. Standard market variety, very large fruit and enormous yielder. Oz., 25c.; $\frac{1}{4} \mathrm{lb}$. $7 j \mathrm{c} . ;$ lb., $\$ 2.50$.

Large Squash. Per oz., 25c.; $\frac{1}{4}$ 1b., 75c.; 1b., \$2.50.

Cherry Red. A small round variety. Per oz., 25c.

Smali Chill. Best variety for pepper sauce. Per 0z., 25c.

Long Red Cayenne. Fruit bright coral red. Per oz., 25c.

N. B. Growers of peppers will do well to try our strain of Sweet Mountain.

\section{PARSNIPS.}

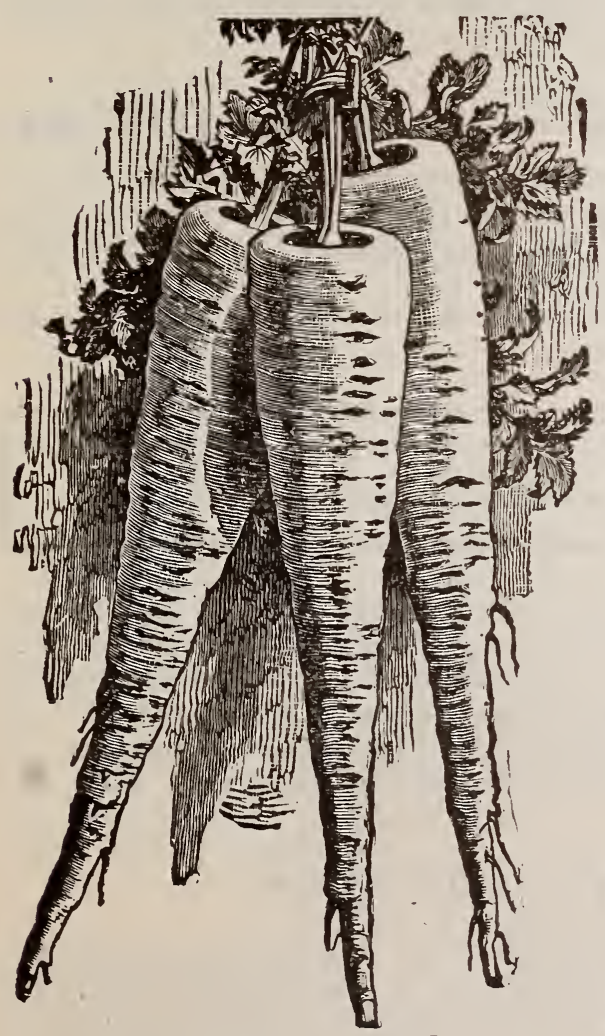

Improved Hollow Crowned.
The Parsnip is

one of our special-

ties. We raise

annually a great

many hundred

pounds and our

stiain is the smooth-

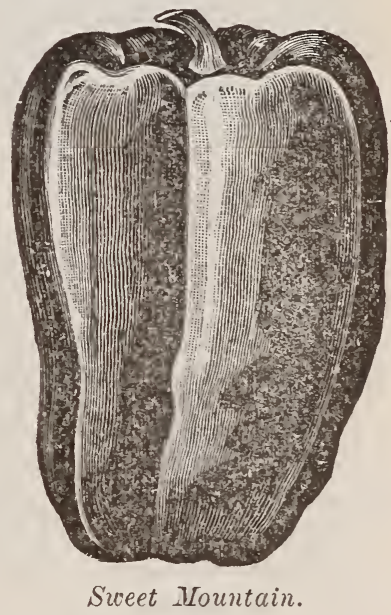

est and finest in existence.

Long Smooth or Hollow Crowned.. Price per pkt., 5c.; Oz., IOc.; $\frac{1}{4} \mathrm{lb}$., I 5 c.; lb., 5 Oo.; $5 \mathrm{lb}$. lots at $40 \mathrm{O}$. per $\mathrm{lb}$.

I wish to state that we have had very gocd luck with the seeds that you sent us. They were good seeds indeed.

Geo. I.inzmayer, New Nonmouth, N. J.

I have always been pleased with the seeds I have received from you, and best of all they have proved true to name.

Albert Brown, Canton, Me.

I grew a large crop of potatoes from the one barrel I got from you last spring. I shall want several barrels next spring.

J. L. Wheatley, Federalsburg, Md.

The grass seed I bought from you turned out all right. My new lawn looks elegant.

John S. Critchley, Rowley, Mass.

Remember we handle grass seed by the car load, and it will pay you to drop us a line for prices or sead vour order. We will always make lowest passible prices on High Grade seed. 


\section{POTATOES.}

Nothing on the seed list requires more care and attention than the Seed Potatoes. Nothing with the average seedman receives so little. Careful as he may be about other seeds he will buy his stock of seed potatoes where he can get the MOST for his money and his customers suffer thereby. We have made a study of the seed potato question. We have obtained stock seed of the leading sorts listed below, which are very pure and true. We have storage facilities for 12,00o barrels in Maine. We employ there expert seed potato men to place our seed with the farmers, to receive, care for and ship the crop, and by this careful and well-developed method we are in shape to give your orders for Seed Potatoes prompt and satisfactory attention.

\section{HOW WE HANDLE OUR SEED POTATOES.}

First. We use great care in selecting our seed stock.

Second. We place this seed in the hands of careful, experienced growers who grow the entire product for us in Aroostook County, Maine, the home of the seed potato.

Third. We personally inspect the growing crops in the field and dig out any impure or off-type specimens which may have appeared.

Fourth. We receive the seed potatoes from the growers and store them in bins especially constructed to carry them through the winter without danger of frost or heating.

Fifth. We ship them in heater cars from the cold north to our warehouses at Now York and Orange, or if your order amounts to a carload, we will ship direct to you and make you a special price besides for so large an order.

\section{Our Seed Potatoes Completely Surround New York City.}

To give an adequate idea of the extent to which our Seed Potato business has grown, if we should place the barrel sacks of 165 pounds each containing the seer? potatoes we sold in I905 flat on the ground each end to end the string would be long enough to completely circle New York City, that is Manhattan Island, a distance of about 16 miles.

"There's a Reason." Our customers know when they order their seed potatoes from us that they will get the right stock.

The fact that we sell each season many carloads of our seed potatoes to brother seedmen and dealers in the trade is pretty good proof of our stock being superior.

Not in many years has the potato crop throughout the United States been as short as the 1905 crop, and while the Maine crop is not as large as the banner crop of 1904, the quality was never better, and this year more than ever we anticipate an unusually heavy demand for the "best seed potatoes that grow." We have tried to plan to meet the largely increasing demand by erecting two new large storehouses at our growing points in Maine, which together with our newly leased large warehouse at Queens, Long Island, and our ample facilities both at New York City and Orange will enable us to care for all wants in the best possible manner.

\section{VARIETIES OF SEED POTATOES.}

Ensign Bagley. We head the list with this most popular sort. Introduced by us in 1899, this potato is now more sought after than any other early sort wherever it has been tried. So great has been the demand for this sort that we last year p'anted one hundred acres, and the entire product of this crop will be sold by us to market gardeners for seed in this country, in Canada and ln England, during the coming planting season. Prices, lb., I5c.; pk., 50c.; bu., \$1.6o; - barrel sack $16_{5} 1 \mathrm{bs}$., \$3.50.

Many dealers for the past few years have sold substitutes for this potato as true Ensign Bagley. Buy your seed direct from the originator and insure pure seed. 


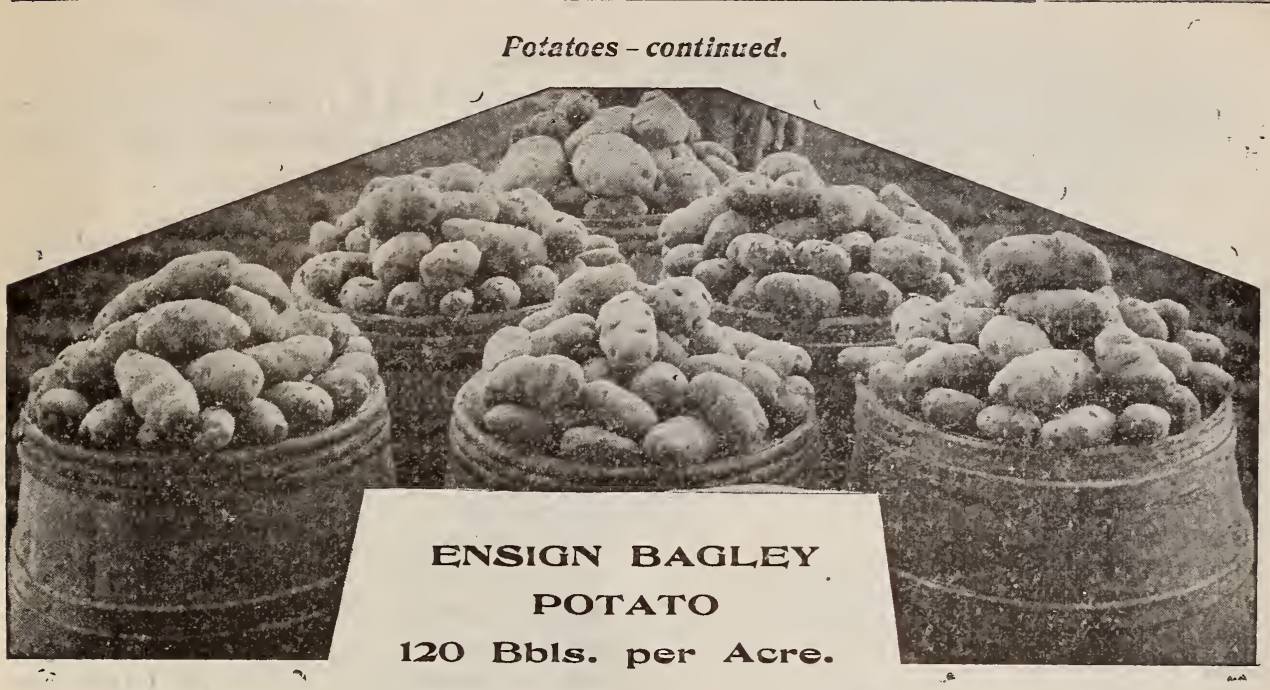

\section{WHAT SOME FEW OF OUR CUSTOMERS SAY OF ENSIGN BAGLEY POTATOES.}

The Ensign Bagley Potatoes I bought of you last spring gave good satisfaction, all you claim for them and more, buth in yield and q iality; have always found your seeds reliable.

S. G. Young, Voluntown, Conn.

The Bagley potatoes purchased of you in Igor and 1902 yielded very good and I am well satisfied with my crop both years.

L. E. Lindeman, Woodstock, Conn.

I will say your Ensign Bagley potato was fine, the best I have ever had, and Admiral Foote are fine also.

W. M.Emerson, Concord, N. H.

The Bagley potatoes have been fine. None are earlier around here.

A. H. Jourdan, Grafton, Mass.

I am very well satisfied with your seeds. Shall buy more extensively next year. I think very high of your Bagley and Foote potatoes.

J. F. CROWELl.

S. D. Woodruff \& Sons,

England, Nov., I, I905.

82 Dey Street, New York.

Gentlemen:-Notwithstanding the unusual interest taken in varieties of seed potatoes throughout Great Brtain during past two or three years and the extreme prices paid for new varieties, we have to say that the Ensign Bagley we have received from you for past two years has taken a deserving place at the top as one of the heavy yielding pure white sorts of splendid quality, the quality being a particular point in this country.

\section{ADMIRAL FOOTE POTATO.}

Admiral Foote Potato is a very desirable second ear'y sort, color of Hebron, shape of Bell Rose. Very prolific and of superior •quality. Price, lb., postpaid, Ijc.; peck, 50c.; bu, \$1.65; bbl. sack 165 lbs., \$3.50; Io bbls., \$33.00.

\section{IRISH COBBLER POTATO.}

The wonderful popularity of this potato is due to its white color, round shape, immense productiveness, superior quality. Can anything more be added to make a perfect potato.

Take warning. Place your order for Irish Cobblers before it is too late to secure the pure stock.

Price, pk., 50c.; bu., \$1.6o; bbl. sack I65 lbs., \$3.50.

We have already at this writing, Dec. 5, 1905, advance orders booked for several carloads each Irish Cobbler and Ensign Bagley, and have already exported to England quantities of Ensign Bagley. 


\section{Potatoes-continued.}

Following general list of pure Maine seed potatoes we offer F. O. B. at nearest point, viz., New York City, Queens, Long Island, Orange, Conn., or at growing point Aroostook Co., Maine. All Canadian shipments are shipped from growing point Maine.

\begin{tabular}{|c|c|c|c|c|c|c|c|}
\hline 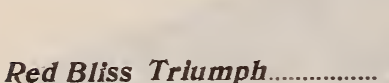 & pk. & $\underset{165}{\mathrm{P}}$ & & & pl, & & $\begin{array}{l}\text { ack } \\
\text { net }\end{array}$ \\
\hline White $B_{1}$ iss or Pride of the & & & & White Elephant (true) & .40 & I. 25 & 3.00 \\
\hline South & .50 & I.40 & 325 & Burbank ....... & .40 & I. 25 & 3.00 \\
\hline 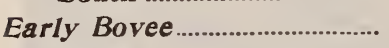 & .50 & I. 25 & $\begin{array}{l}3.25 \\
3.25\end{array}$ & White Star................ & .40 & I. 25 & 3.00 \\
\hline Delaware & .40 & 1.25 & 3.00 & American Wonder.. & .40 & I.25 & 3.00 \\
\hline 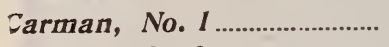 & .40 & I.25 & 3.00 & Clark's No. 1 ... & .50 & I.25 & 3.25 \\
\hline Zarman, No. 3 . & .40 & 1.25 & 3.00 & Early Harvest.... & .50 & 1.25 & 3.25 \\
\hline 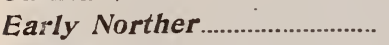 & .50 & I. 25 & 3.25 & Early Ohio........... & .50 & I. 25 & 3.2 \\
\hline Polaris or Puritan & .50 & 1.25 & 3.25 & Early Fortune... & .50 & I.25 & $3 \cdot 23$ \\
\hline New Queen & .40 & I. 25 & 3.25 & Aroostook Prize... & .40 & I.25 & 3.00 \\
\hline Empire Stat & .40 & I. 25 & 300 & Maggie Murphy... & 40 & 1.25 & 3.00 \\
\hline Rural New Yorker, No. $2 \ldots$ & .40 & I. 25 & 3.00 & Belle Rose & .40 & I. 25 & 3.00 \\
\hline Green Mountain & .40 & I. 25 & 300 & State of Maine & .40 & I.25 & 3.00 \\
\hline Early Rose & .50 & I. 25 & 3.00 & Maule's Thoroughbred........ & .40 & I.25 & 3.25 \\
\hline Beauty of Hebron (early)......... & .40 & 1.25 & 3.25 & Sir Walter Raleigh ................. & .40 & I.25 & 3.00 \\
\hline
\end{tabular}

Write for prices of any sort not above listed.

Paris Green. Strictly pure, 20c. lb ; Io lbs. and over at I8c.; 50 lbs. or more @ I6c. per lb.

\section{IMPORTANT.}

We are glad to quote special prices m l irge lots of seed potatoes. Frequently we are able to make a close price on a carload of potatues to go to one section. Shall be glad to have our customers write us for prices.

\section{PUMPKINS.}

\section{(Add 8 cents per lb. If sent by mail.)}

Large Cheese. Sweet and well flavored. Pkt., 5c.; oz, IOc.; $\frac{1}{4}$ lb., I5c.; lb., $40 c$.

Winter Crookneck. Old standard sort, good keeper. Pkt., 5c.; oz., Ioc.; $\frac{1}{4}$ lb., I5c.; lb., $40 c$.

Connecticut Field. The common large yellow pumpkin, excellent for stock; very heavy cropper. Price per oz., 5c.; $\frac{1}{4}$ lb., Ioc.; lb., 3oc.; qt., 20c.; bu., \$3.0o.

Tennessee Swaet Potato. Medium size, pear shaped. Pkt., 5c.; oz., Ioc.; $\frac{1}{4}$ lb., 20c.; lb., toc.

King of the Mammoth or Genuine Mammoth. This is the largest of all pumpkins, growing to an immense size, three feet or more in diameter, and weighing from 100 to 200 or more pounds. Pkts., 5c.; oz., IOc.; $\frac{1}{4}$ lb., 25c.; lb., $75 \mathrm{c}$.

Small Sugar. A very prolific golden colored sort, averaging about Io inches in diameter. Plkt. 5c.; Oz., IOc.; $\frac{1}{4}$ lb., I 5c.; lb., $50 c$.

All of my seeds gave good results; the parsnip seed was very fine, corn very good.

$$
\text { J. R. C., Wallingford, Conn. }
$$

Last spring I bought of you one packet Mammoth Pumpkin seed and it was very late when I planted them. From ONE viNe I got five pumpkins that weighed as follows, 37, 53, 55, 6I, 84, total weight from the one vine of 290 lbs. No special care or fertilizer. Three of the largest are now in my cellar.

F. H. King, Barkhemsted, Ct., N ov. 2I, I904. 


\section{RADISH.}

No vegetable can be produced with as little care as the radish. Started in the house in small boxes or in a small hotbed they are soon ready for use. They may be sown in open ground very early in the spring.

\section{Forcing Varieties.}

(Add 8 cents per $1 b$. if sent by mail.)

Vick's Scariet Globe. Per pkt., 5c.; oz., Ioc.; $\frac{1}{4}$ lb., 20c.; lb., $50 c$.

Scarlet Globe White Tipped or Rosy Gem Extra Early. Maturing in 22 days. Per pkt., 5c.; oz., Ioc.; $\frac{1}{4}$ lb., 20c.; lb., $50 c$.

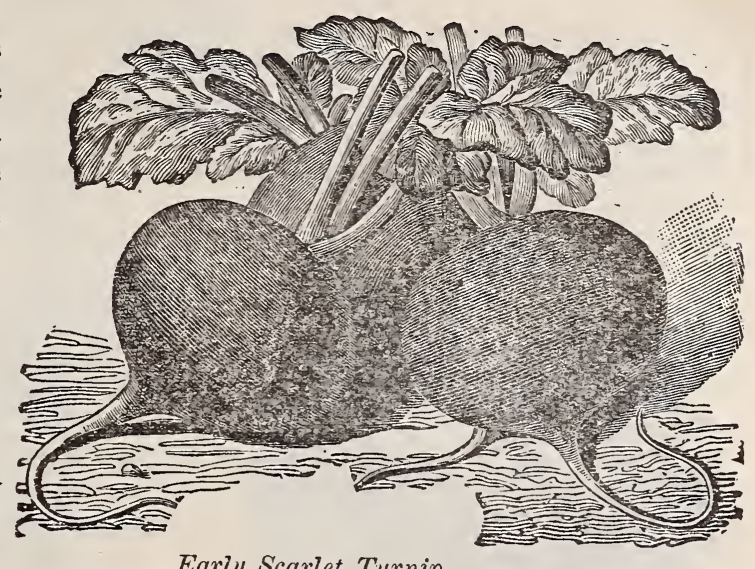

\section{RADISH-SUMMER VARIETIES.}

Our Radish seed is all of very best French growth, which is best the world produces.

All following varieties at uniform prices; pkt., 5c.; oz., IOc.; $\frac{1}{4} \mathrm{lb}$., I $5 \mathrm{c}$; $1 \mathrm{lb}$., $50 \mathrm{c}$.; Io lbs. or over at $40 \mathrm{Oc}$ lb.; $50 \mathrm{lbs}$. or over at $35 \mathrm{c}$. lb., either one or assorted.

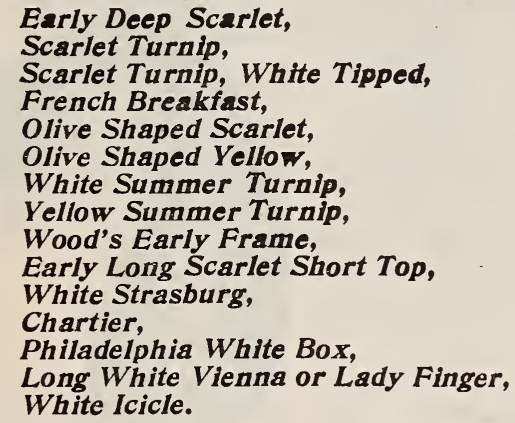

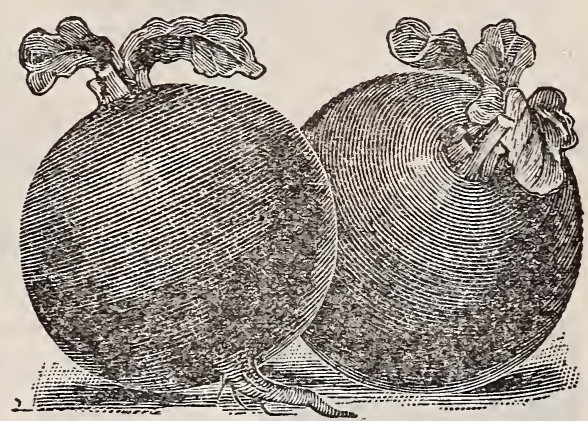

Vick's Scarlet Globe.

\section{WINTER RADISHES.}

Half Long Black. (Extra fine strain). pkt. oz. 1//1b. $1 \mathrm{~b}$. Black Spanish or Fall. (Round) .... $\$ .05 \$ .10 \$ .20 \$ .60$ Black Spanish or Fall. (Long) ............................................................................. $\begin{array}{llllll}\text { China Rose or Winter. Skin fine and bright rose colored........................................... } & .05 & \text {. I0 } & \text {.20 } & .70\end{array}$

I can recommend Woodruff's seeds. I send you the names of a few of my friends who would like your catalogue.

\section{SALSIFY OR OYSTER PLANT.}

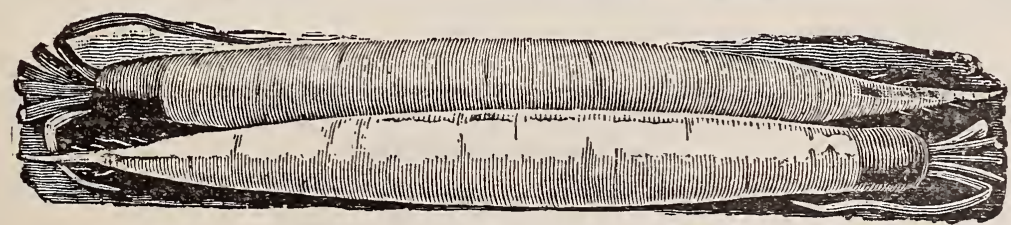

Sandwich Island Mammoth Salsify.

Mammoth Sandwich Island. This variety originated in the Sandwich Islands; of enormous size, more than double the size of the ordinary kind. Roots grow long, large, smooth and white, and of exceedingly tender quality. Price per pkt., 5c.; oz., I5c.; $\frac{1}{4}$ lb., 30c.; lb., $\$ 1.00$. 


\section{SPINACH.}

We are headquarters on Spinach Seed, and supply annually the most critical of customers. Buying as we do in such large quantities we are enabled to sell at corres= pondingly low figures.

We offer the following standard varieties, all of very best stocks, at the following uniform prices: per oz, jc, $\frac{1}{4} \mathrm{lb}$, IOc; lb., 30з.; Io ib. lots at 20z; $50 \mathrm{lb}$. lots and over at I4c. lb.

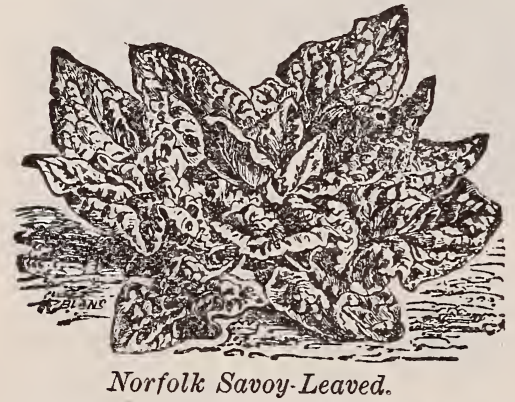

(Add 8 cents per 1b. if sent by mail.)

All following test imported stocks.

Round Thick Leaf. One of the very best for early Spring and Fall sowing.

Norfolk Savoy=Leaved. (Bloomsdale). Curled and wrinkled like a savoy cabbage. (Imported seed).

Giant or Monstrous Virofiay. Leaves very large.

Long Standing. Does not run to seed as quickly as some of the other varieties.

New Victoria. A new, very long standing sort.

American Grown Bloomsiale Savoy. To supply the demand for new crop spinach seed for snwing same year seed $i$ grown, we have this variety grown in America as well as abroad. We offer the new cro, sed icaly or silip i:ent $\Lambda$ u ;. I5 to 20, 1b., 25c.; Io lbs. @ I8c ; 100 lbs. @ I4c.; 1000 lbs. (a) $13 \mathrm{c}: \mathrm{b}$.

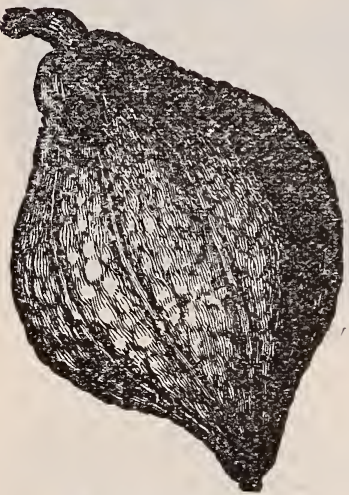

Hubbard Squash.

\section{SQUASH.}

Pkts. each sort, $5 \mathrm{c}$.

Ounces each sort, Iro.

s: mmer Cronkneck. Standard Summer sort; $\frac{1}{4}$ lb., 20c.; 1b., 6oc.

Giantê Summer Crookneck. Larger than above; $\frac{1}{4}$ lb., 2oc.; 1b., 6oc.

White Bush Scallop. White and flat, with scalloped edges; $\frac{1}{4} \mathrm{lb}$., 20c.; lb, 6oc.

Mammoth White Bush Scallop. Large fruited, Io to 14 inches in diameter; $\frac{1}{4} \mathrm{lb} ., 25 \mathrm{c}$; lb., 7oc.; 5 lbs. or more @ 6oc. 1b.

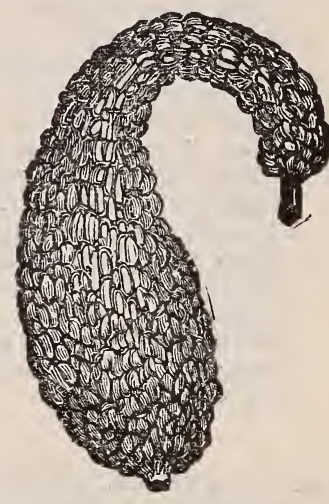

Crookneck Squash.

Boston Marrow. Bright orange co!or, standard sort Per $1 / 4$ 1b. Per $1 b$. Hubbard. ' I lard, dark green, excellent quality ...................................................................... $=0$

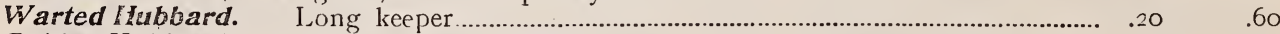

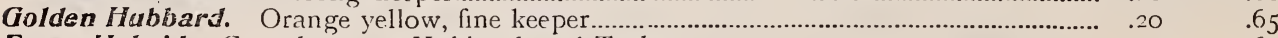

Essex Hybrid. Cross between Hubbard and Turban.................................................................. $\quad .20 \quad .60$

Orange or Prolific Mastow. Resemb!es Boston Marrow ………......................................

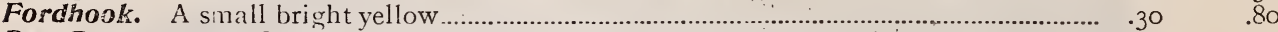

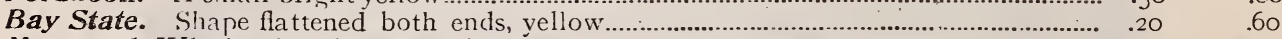

Mammoth Whale. 'The largest variety .................................................................................... 40 I.2O

\section{SUNFLOWER.}

Yankee ingenuity has led some to utilize the tali sunflower sta'ks for bean poles. Excellent also tor parrot food.

Mammoth Russian or Large Grey Seeded. Price per plst, 5c ; qt, I5c.; pk, 6oc.; bu., \$2.00.

Your stock of Hubbard Squash beats the world. From one acre I grew 390 barrels of the finest and truest specimens I ever saw.

Dec. 2, 1904 .

W. L. Tibbetts, Queens County, N. Y.

Our stocks of Hubbard and Wartel Hubbard Squashes are exceedingly pure and uniform in type.

Remember we pay the freight. Seepage 1 . 


\section{TOMATOES.}

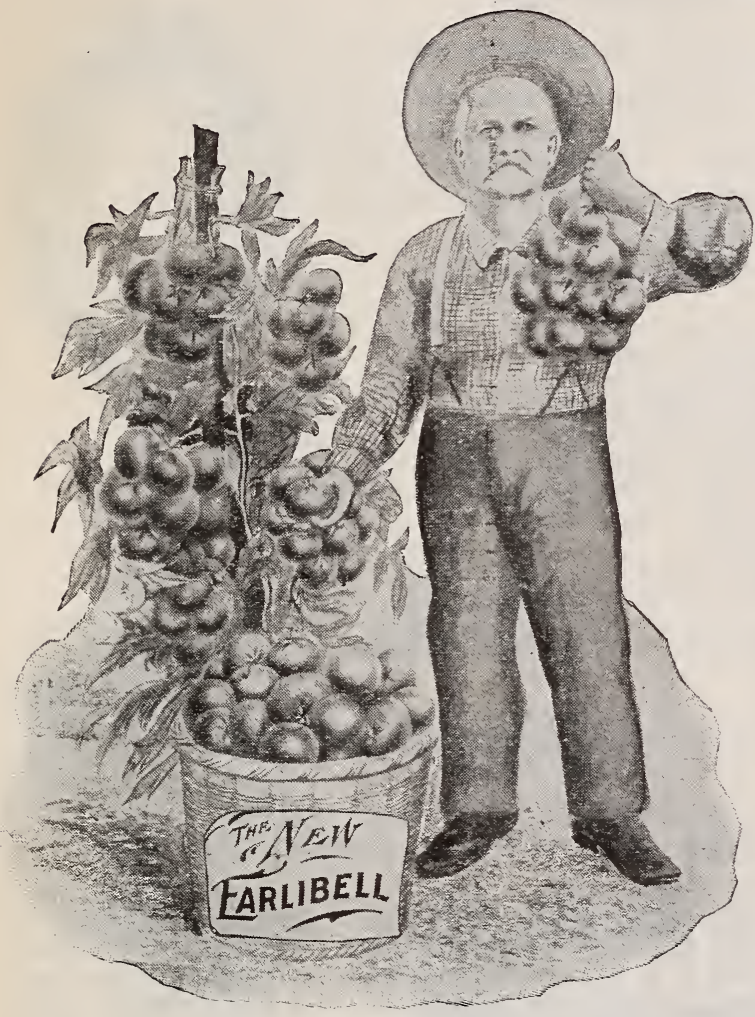

New Earlibell Tomato.

Earlibell Tomato. We have in this a brand new extra early sort that we are sure when known will surpass in popularity and demand the Earliana. It is an extra early sort the fruits of which are larger and smoother than Earliana and a marked advantage over that popular sort is that it will continue bearing much longer than Earliana, the plants remaining green. We most heartily recommend all who want the finest extra early sort yet introduced to try it. The illustration shown is a reproduction from photograph. Pkt., IOc.; OZ., 50c.; $\frac{1}{4}$ lb., \$1.50; lb., \$5.50. Supply of seed very, very limited.

Spark's Earliana. This has again demonstrated the claim that it is without doubt the very best of the earliest bright red sorts. It is an immense cropper and fairly good quality. Pkt., IOC.: oz., 30c.; $\frac{1}{4}$ lb,$\$ 1.00 ; 1 b ., \$ 3.50$.

Chalk's Early Jewel. IVithin one week as extremely early as the famous Spark's Earliana, the fruits are uniformly larger, thicker through, more solid, and of finer quality. The plants are immensely productive; it is one of the most profitable tomatues to grow for main crop. Price same as Spark's Earliana.

Livingstone New Globe. A new globular shaped solid sort. Plkt., Ioc.; OZ, 4OC.; $\frac{1}{4} \mathrm{lb}, \$ 1.25$.

Liberal pkts. 5c each; 20c. per oz., of a!l following varieties.

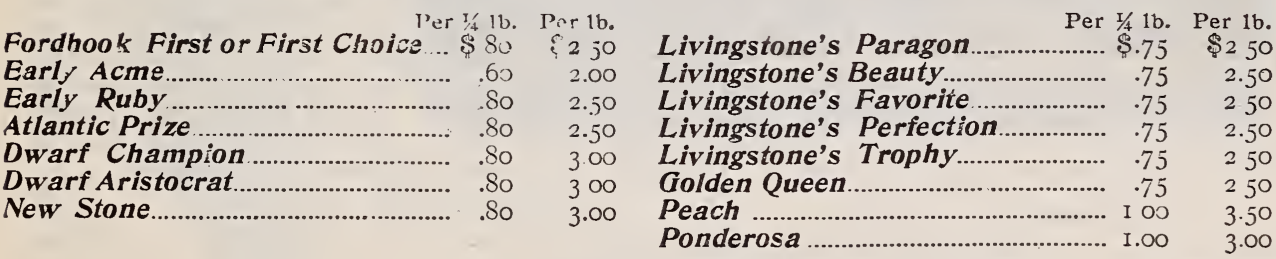

\section{PICKLING VARIETIES OF TOMATOES.}

Yellow Plum, Red Pluin, Yellow Cherry, Red Cherry. Pric of each par pkt., 5c.; oz., 30c.

Dear Sirs:-From $\frac{1}{2} \mathrm{lb}$. of New Stone Tomato purchased of you this season I made a profit of over $\$ 500$. Book me for I 1 b. for next season and give me the same strain of seed.

Queens Co., L. I., Dec. I, '05.

John J. Wagner, Jr.

Seymour, Ct., Nov, 25, 1905 .

From I acre and 3 rods of ground sowed with your Long Island Ruta Baga turnip seed in drills, I harvested $\mathrm{I} 200 \mathrm{bu}$. turnips. 'The only fertilizer I used was $\frac{1}{2}$ ton Woodruff's Home Mixture that cost me \$14.00 Not a forkful of stable manure. This is what I call a satisfactory crop. I so!d all but 100 bu. of them @ 50c per bu. Those I fed out as they were too large for market.

JAMES BRENNAN, 


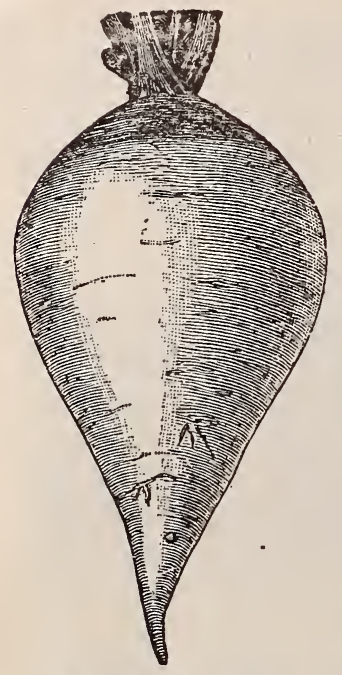

Breadstone Turnip.

\section{TURNIPS.}

\section{(Add 8 cents per $1 \mathrm{~b}$. If sent by mall.)}

The turnip is so commonly cultivated and sô widely known that we will not describe in detail the several varieties. We produce nearly all our own turnip seed, and can vouch for its purity âñत trueness of stock.

All varieties 5c. per oz.; I 5c. per $\frac{1}{4} \mathrm{lb}$.

IVhite Egg.

Early White Flat Dutch

Early White Strap Leaf..

Early Red Top Strap Leaf.

Long White or Cow Horn.

Yellow or Amber Globe

Extra Early Purple Top Milan............... . 40

Extra Early White Top Milan.......................... $\quad .60$

Yellow Aberdeen

Red Top White Globe

Pomeranian or Large White Globe.............. $\quad .40$

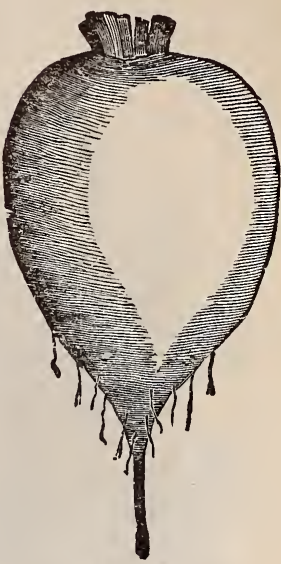

White Egg.

Swedish or Ruta Baga Varieties.

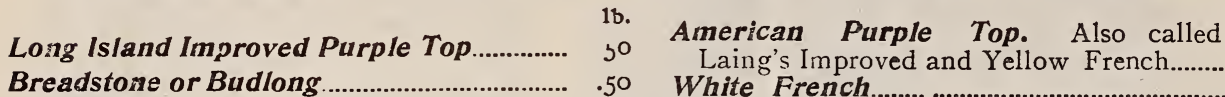

(Five lbs. of one or assorted varieties at $5 \mathrm{c}$. per lb. less than above prices,)

SWEET, POT AND MEDICINAL HERBS.

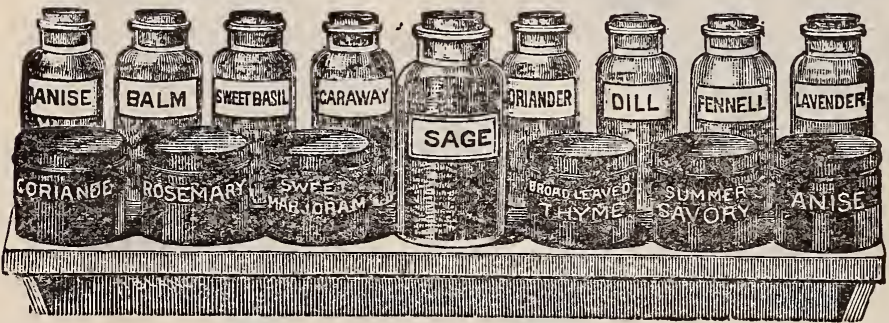

Every garden should have its complement of Sweet Herbs. We can all appreciate their utility, both for summer flavoring and their opportune use medicinally. Their culture is so easy that none ought to be without them. Sow the seed in pan or seed bed in early spring, transplant as soon as weather will permit. Cut them when not quite in full bloom and hang in shady places to dry. Pack away in box entirely excluded from the air.

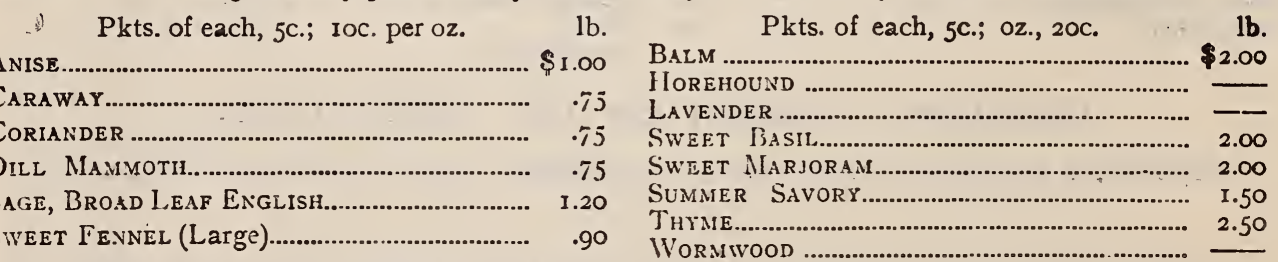

(Seven packets herb seeds for 25 cents.)

\section{GRASS SEEDS.}

We invite particular attention to our Hirh Graje Grass Seeds. We buy our Grass Seejs in carioad lots direct from the West, and a-e prepared to mate extremely close prices for lest grades.

Always fleased to mail samples and quote bottom prices. Following prices are net cash, not subject to discount, F. O. B., Orangs or New York. 


\section{Grass Seeds-continued.}

Red Clover Medicm. Price per lb., i 5 c.; per bu. of 60 lbs., $\$ 8.50$.

Red Clover Mammoth Price per lib., iGc.; per bu. of 60 lbs., $\$ 8.50$.

Alfalfa or Lucerne Clover. Price per lb, i6c.; per bu. of 60 libs., $\$ 8.75$.

Al.sike or Hybrid Clover. Price per lb, i6c.; per bu. of $60 \mathrm{lbs}, \$ 8.50$.

White Clover. Price per lb., 20c.; 10 lbs., \$1.80; $100 \mathrm{lbs}$., \$16.00.

Crimson or Scarlet Clover. Price per lb., i $2 c$.; per bu. of 50 lbs., $\$ 6.00$.

Hungarian Míllet. Price per pk., $40 \mathrm{O}$; ; per bu. of $48 \mathrm{lbs}$., \$1.40.

Golden or Grrman Millet. Price per pk., 4 Oc.; per bu. of 48 lbs., \$r.40.

Timothy. Price per lb., IOc.; prr bu. of $451 \mathrm{bs}$., $\$ 1.75$ and $\$ 2.00$.

Red Top Fancy Recleaned. Price per lb., IOc.: extra cleaned seed.

Kentucky Blue Grass. Price per lb., izc.; per bu. of $1+\mathrm{lbs}, \$ 1.35$.

Orchard Grass. Price per lb., i5c.; per bu. of It lbs., $\$ 1.8_{5}$.

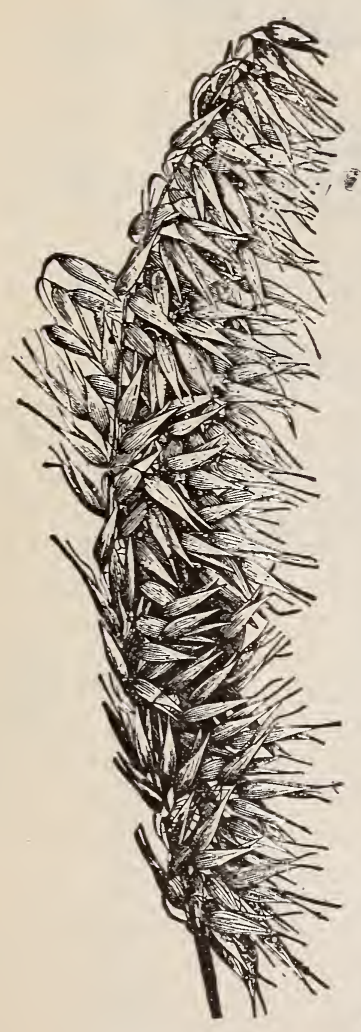

Lincoln Oxts.

\section{SEED OATS.}

Prices net, not subject to discounts. F. O. B., Orange, Conn.

The Seed Oats we offer are the heaviest, pimpest and finest samples we have ever seen. All put up in sacks of $2 \frac{1}{2}$ bu. each, no charge fcr bags. All are Ohio grown and selected from heaviest producing crops.

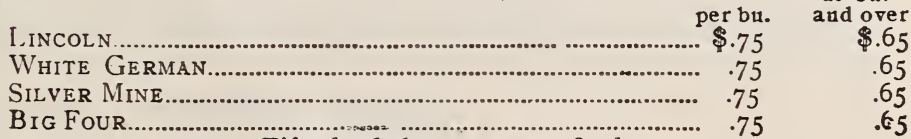

Fifty bushels or over at $58 \mathrm{c}$. bu.

BUCKWHEAT.

JAPANese. Large grained, immense yielder. Per bu., \$I.r5. 5 bu. or over, \$1.05 per bu.

\section{JAPANESE BARNYARD MILLET. (Panicum Crus Galli.)}

This wonderful and valuable new forage plant was introduced in this country by Prof. Brooks of the Massachusetts Agricultural Experiment Station. It has proven an enormous yielder in all sections of the United States where tried-hay and fodder of the most excellent quality growing on any soil, yielding 12 to 20 tons per acre, and growing 5 to 8 feet in height. Cattle and horses eat it greedily. Sow in May and June broadcast, Io to I2 pounds per acre, or in drills, $8 \mathrm{lbs}$. per acre. Prices, lb., I 5c.; (by mail, postpaid, lb.. 25c.;) ro lbs., \$1.00; bu. of 32 lbs., \$1.80 by freight or express.

\section{LAWN GRASS MIXTURE.}

Our Lawn Mixture is composed of the finest recleaned grass seeds (not of the cheap, light chaff, weighing but I 5 lbs. per measured bushel as put up by most seedmen.) Our Lawn Grass Seed weighs about 20 Ibs. per measured bushel.

\section{THE QUANTITY REQUIRED.}

The quantity required for making new lawns is 4 bushels per acre, or for renovating old lawns, 1 to 2 bushels. For a plot $15 \mathrm{x}$ 20 , or 300 square feet, 1 quart is required for new, or 1 pint for renovating old lawns.

Drices, 20c. par qt., 90c. per pK., $\$ 3.75$ per bu. (If by mall, add at the rate 5c. per quart) Grafting Wax. Price per $\frac{1}{4}$ lb., IOc.; $\frac{1}{2}$ lb., I 5 c.; 1b., $25 \mathrm{c}$.

\section{BARLEY. BARLEY. BARLEY.}

We are headquarters on Barley. For sowing for a forage crop is being used very extensively. The early frosts do not kill it and it can be pastured clear into the winter. If cut in September it makes good hay. Price perbu., \$1.10; 5 bu. lots at $\$ 1.00$ Der bu.

White Canada Field Peas in 5 bu. lots @ $\$ 1.50$ per bu.

Prices on all of above Field Seeds, Millets, etc., are subject to market fluctuations, and net cash, no discounts. 


\section{SWEET PEAS.}

Prices are for seeds by mail, postpaid, and our stocks are unsurpassed in purity and vitality, and are true to name. The following named varieties are a very select co:lection of the best and most reliable free bloomers with brilliant colorings. All at a uniform price of pkt , 5c.; oz., IOc; $\frac{1}{4} \mathrm{lb}, 25 \mathrm{c}$; lb., 75c., postpaid.

Emily Henderson. Pure white.

LotTie Eckford. Lavender. white.

Extra Early Blanche Ferry. Pink and

Prince of Wales. Bright deep rose.

Prima Donna. Beautiful light pink.

MRS. KÉNYON. Large, primrose.

Miss Wilmot. Orange pink.

Aurora. Striped orange salmon.

OThello. Deep maroon.

Navy Blue. Rich, deep true blue.

Lady Grisel Hamilton. Lavender.

Blanche Burpee. Finest pure white.

Emily Eckford. Reddish mauve, wings blue.

LOVELY. Shade of pink on white.

Salopian. Bright red.

One packet each above I5 varieties for 6oc.; one oz. each, \$1.25.

The dwarf or cupid varieties of Sweet Peas are becoming more popular each year, and we offer the following all dwarf or cupid sorts. Pkt., $5 \mathrm{c} . ; \mathrm{oz}$, IOc.; $\frac{1}{4} \mathrm{lb}, 30 \mathrm{c} ; \mathrm{lb} ., \$ 1.00$

White Cupid, Pink Cupid, Primrose Cupid, Benuty Cupid, Alice Eckford Cupid. One pkt. each of the five varieties of Cupid, 2oc.; one oz. each of the five varieties of Cupid, $40 \mathrm{oc}$

\section{BUSH SWEET PEA.}

Gray Friar. Pkt., IOc.; Oz., I5c.; $\frac{1}{4}$ lb., 40c.; 1b., \$1.25.

\section{SUPERB MIXTURES OF SWEET PEAS.}

Trial Ground Mixture. Mixture of over 50 named sorts

Per oz Per $1 / 4$ 1b. L'er 1 b.

ECKFORd's FinEST MIXED. Large flowered, free bloomers. $\$ .05$ .05

Phlox Drummondil. Finest mixed. Price per pkt., 5c.; oz., $75 \mathrm{c}$.

Poppy. Carnation Flowered. Double mixed, 2 feet. Price per pkt., 5c.

Poppy. French. Papaver (Rhras) Ranunculus flowered, double mixed, 2 feet. Pkt., 5c.

Poppy. Mixed German. Price per plit., 5c.

Portulaca. Splendid mixed, all colors, single. Price per pkt., $5 \mathrm{c}$.

\section{PANSIES.}

Choicest Mixed German

Per pkt, Per oz

\$.IO

Giant Trimardeau Mixed. Great mixture, immense blooms................................................... . I5

BelgIAN OR FANCY MIXED. None better obtainable................................................................... . I5

Petunia. Fine single mixed

.15

Ricinus. (Castor Oil Bean), mixed

Scabiosa. (Mourning Bride), double dwarf.

Stocks or Gillyflower. Dwarf German, ten weeks, mixed

" " Dwarf, pure white

" " Large flowering, mixed

Sunflower. (Helianthus.) Tall, single...

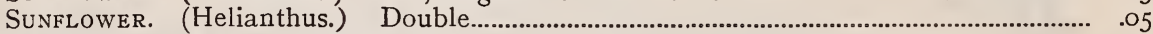

SAlvia Splendens. Scarlet Sage....................................................................................................... 05

SWEET WILLIAM. Double mixed ............................................................................................... . .

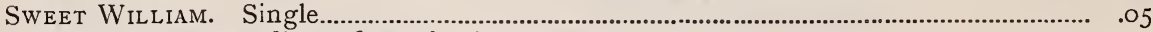

VERBENA HYBRIDA. L Lixtra fine mixed......................................................................................... .IO

VERBENA MAMMOTH FlOWERED ...................................................................................................... . I5

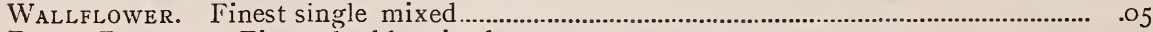

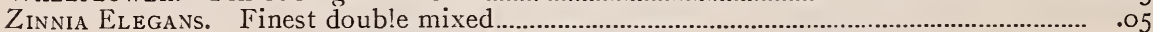

Mixed Wild F lower Garden Seeds. Mixture of over twenty varieties of annuals......... .05

Tubercses. Excelsior Double Pearl, extra large bulbs, three for IOc.; 25 c. per doz.; \$ I.50 per Ioo by express. Add Ioc. per doz. if by mail.

Fine Mixed Gladioli. Our mixed Gladioli embraces a magnificent variety of beautiful colors.

First Size Bulbs, guaranteed to flower; extra fine mixed, four for 1oc.; $25 \mathrm{c}$. per doz.; 50 for $\$ 1.00$ or $\$ 1.75$ per Ioo, postpaid.

By express, $\$ 1.25$ per I00; $\$$ II.00 per I,000. 


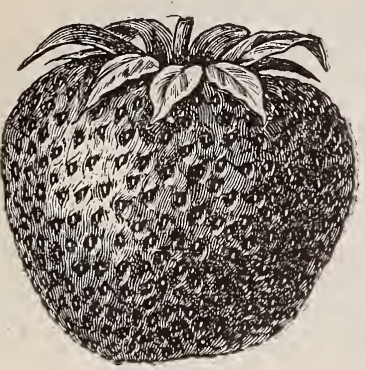

Abundance Strawberry.

Per doz, 4 oc.

IOO, \$1.00,

I,000, \$4.00.

Rhubarb Roots. Strong roots. Price per doz., 8oc.; per ioo, $\$ 4.00$.

Horseradish Roots. Strong cuttings. Price per Ioo, 6oc.; per I,000, \$3.00.

\section{SMALL FRUITS.}

N. B. Prices of all small fruits are net, not subject to dissounts. We offer following assortments of small fruits. We can fill orders promptly and shall be pleased to quote special prices on large lots. Prices are net, no discounts.

\section{STRAWBERRIES.}

All plants shipped in best possible manner at purchaser's risk of damage in transit. All our own Connecticut home grown plants, fresh dug to order, sure to live and do well.

Abundance Strawberry. Abundance produces a crop every time when all other sorts fail. We have now a fine lot of plants and offer them at following very low price: doz., 40c.; I00, \$1.00; 1,000, $\$ 4.00$.

P-Indicates perfect flowered sorts. I-Imperfect flowered sorts.

\section{Pice Half dozen at dozen rates, 50 at hundred rates an 1
500 at thousand rates.}

\begin{tabular}{|c|c|c|c|c|c|c|c|}
\hline Abundance...................... & $\begin{array}{l}\text { Per doz. } \\
\text { postpaid } \\
\$ .50\end{array}$ & $\begin{array}{l}100 \mathrm{Ex} \\
\text { totot pd. } \\
\$ 2.50\end{array}$ & $\begin{array}{l}1000 \text { Ex. } \\
\text { not pd. } \\
\$ 7 \cdot 5^{\circ}\end{array}$ & $\mathrm{P}$ & $\begin{array}{c}12 \text { by mail } \\
\text { postpaid } \\
\text { Morning Star..................... }\end{array}$ & $\begin{array}{l}100 \text { Ex. } \\
\text { not pd. }\end{array}$ & $\begin{aligned} 1000 \mathrm{Ex} . \\
\text { not pd. } \\
\quad \ldots \ldots . .\end{aligned}$ \\
\hline Aroma & .30 & .50 & 4.00 & $\mathrm{P}$ & Marshall ......................... \$.30 & $\$ .50$ & $\$ 3.50$ \\
\hline 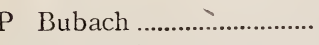 & $\cdot 30$ & .50 & 3.00 & I & Miller ............................... & .50 & 300 \\
\hline Bismarck ........................... & $\cdot 30$ & .50 & 3.00 & $\mathrm{P}$ & Nick Ohmer....................30 & .60 & 3.50 \\
\hline Brandywine .................... & $\cdot 30$ & .50 & $3 \cdot 50$ & $P$ & President.......................... & .60 & $3 \cdot 50$ \\
\hline 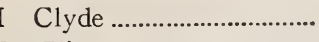 & $\cdot 30$ & .50 & 3.00 & I & 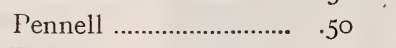 & .60 & $3 \cdot 50$ \\
\hline 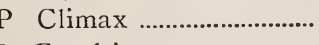 & .25 & .50 & 2.50 & I & Parson's Beauty .............. & .60 & 3.00 \\
\hline 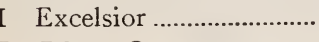 & 30 & .30 & 3.00 & I & 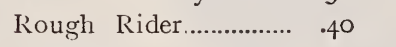 & .60 & 400 \\
\hline Edgar Queen.................. & $\cdot 30$ & .50 & 3.00 & $\mathrm{P}$ & 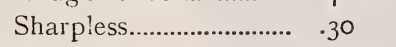 & .50 & 3.00 \\
\hline Gandy & .30 & .50 & 3.00 & $\mathrm{P}$ & 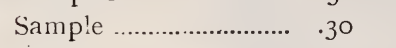 & .50 & 3.00 \\
\hline 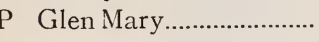 & $\cdot 30$ & .50 & $3 \cdot 5^{\circ}$ & I & Senator Dunlap.............. & .50 & 3.00 \\
\hline 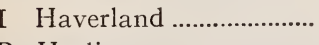 & .25 & .50 & 300 & I & 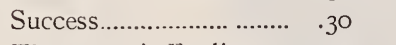 & $\cdot 50$ & $3 \cdot 50$ \\
\hline Haslin & .40 & .75 & 400 & I & Thompson's Earliest.... & .75 & 400 \\
\hline 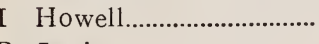 & .40 & .60 & 400 & I & 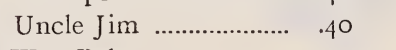 & .75 & 4.00 \\
\hline 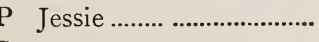 & .25 & .50 & 350 & I & Wm. Belt.................................. & .50 & 3.00 \\
\hline 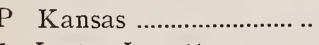 & .40 & 60 & 4.00 & I & World's Champion...... & .75 & 400 \\
\hline Lester Lovett.................... & $\cdot 30$ & .75 & 8.00 & & & & \\
\hline Mark Hanna ..................... & .50 & r.oo & 6.00 & \multirow{2}{*}{\multicolumn{4}{|c|}{ CASH ORDERS. }} \\
\hline 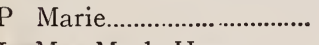 & .25 & .50 & 3.50 & & & & \\
\hline Mrs. Mark Hanna......... & $\cdots$. & …...... & ......... & \multirow{2}{*}{\multicolumn{4}{|c|}{$\begin{array}{l}\text { All orders, accompanied by cash, amounting to } \\
\text {,ooo plants, } 5 \text { per cent. off, }\end{array}$}} \\
\hline 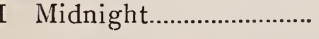 & . $\quad \ldots$. & ......... & ......... & & & & \\
\hline
\end{tabular}

R.aspberries, (Black Caps). Kansas, Conrath, Greģ. Price of any above standard sorts, per doz., 50c.; IOO, \$1.30; I,000, \$1 2.00.

Cumberland. Per doz., 50c; per Ioo, \$1.6o; per r,ooo, \$14.00.

Red Raspberries. Cuthbert, Marlboro. Per doz., 50c.; Ioo, \$1.50; I,000, \$9.00. Louden Shaffer, per doz., 50c.; I00, \$1.75; I,000, \$12.00.

Dewberries. Lucretia. Large, early and sweet. Price per doz., 50c.; 100, \$1.5\%.

Try our nursery stock. Narly everything offered is home grown stock, fresh dug to order and sure to llve. Note our low prices. 
Blackberries. Agawam. Erie, Snyder, Taylor; doz., 50c.; I00, \$2.00; 1,000, \$1600.

Eldorado. Minnewaski, Rathburn; doz, \$1.00; 100, \$3.00; I,000, \$20 00.

IOO, $\$ 4.50$.

Currants. Fay's Prolific, Cherry, President Wilder, No. I; 2 year old plants. Per doz., $75 c_{\text {; }}$;

Cherries. Black Tartarian, Coe's Transparent (white), Gov. Wood (red), Large Montmorency (red), Napoleon (ren and white), Schmidt's (black), Spanish (yellow), Windsor (red), First-class trees; 5 to 7 feet, each 40 .; doz., $\$ 4.50$.

Peaches. A ferv of the hardiest varieties, of good quality, most reliable for New England, ripening in order named. First-class trees, 4 to 6 feet.

Sneed (white), Triumph (yellow), Carman (white), Mt. Rose (white), Champion (white), Early Crawford (yellow), Reeves' Favorite (yellow), Elberta (yellow), Old Nixon (white), Crosby (yellow), Late Crawford (yellow), Fox Seedling (white), Stump (white). All freestones except Sneed. Each, I5c.; doz., \$I.50; I00, \$8.00. First-class trees, 9-16, 4 to 6 feet.

PeArs. Following list comprises the standard sorts to be depended upon in this climate. Firstclass trees $5 \frac{1}{2}$ to 7 feet. Wilder, Doyenne de Te, Clapp's Favorite, Bartlett, Sekel, Vermont Beauty, Sheldon, Buffam, B. D’Anjou, Clairjeau, Kieffer, Lawrence; 35c. each; doz., \$3 50.

European Plums. Lombard, Shropshire, Damson, Bradshaw, Reine, Claude, Apple, Oct. Purple, German Prune. Standard trees, 5 to 7 feet; each, 35c.; doz, \$3.5o.

Japanese Plums. Abundance, Burbank, Chabot, Normunds, Satsuma, Wixon, Red June; 5 to 7 feet trees; each, 35c.; doz., \$3.50.

Grapes. We have selected six varieties to be depended on every season in our New England climate to furnish an abundance of fruit of desirable quality.

Brighton (red), Concord (black), Delaware (red), Green Mountain (white), Niagara (white), Wordon (black). One vine of each of above six varieties, \$1.00; Green Mountain alone, 50c.; other varieties, I5c. All sorts \$1.50 per doz., except Green Mountain, \$3.00.

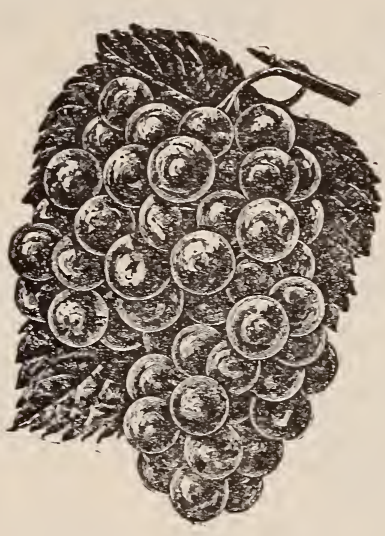

Concord Grape. The old Standby.

Quinces. Orange and Champion. First-class trees of either variety, 35c. each.

APPLES. Ripening in order named:

Summer. Sweet Bough, Red Astrachan, Early Harvest, Golden Sweet.

Autumn. Gravenstein, Maiden's Blush, Fall Pippin, Wealthy.

Winter. Bellflower, Rhode Island Greening, Talman's Sweet, Northern Spy, King Spitzenburg, Hubbardston, Sutton Beauty, Baldwin, Roxbury Russet.

Trees are 5 to 7 feet and first-class. Price, 25c. each; $\$ 16.00$ per I00.

\section{PARIS GREEN.}

Strictly pure; per lb., 20c.; ten lbs. and over, I8c.; $50 \mathrm{lbs}$. and over at $16 \mathrm{c}$. $1 \mathrm{~b}$.

\section{BORDEAUX MIXTURE.}

\section{(In liquid form) for black rot, mildew or blight.}

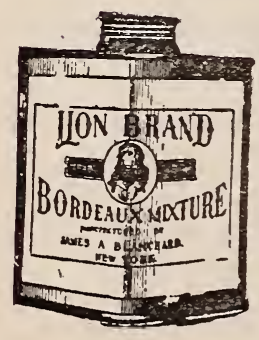

The great increase in blight on Cucumber, Tomato, Potato, Celery, etc, during past few seasons makes it necessary to apply to these crops the well. known preventive Bordeaux Mixture, and since it is somewhat troublesome for the farmer to properly mix the formula we offer Blanchard's Bordeaux Mixture, One gallon of the mixture placed in 49 gallons of water will spray two to three acres of potatoes, etc., if applied with any of the modern spraying carts. Great profit must result in a careful use of this mixture on all crops afflicted by blight.

PRICES: I qt. can, 45c.; I gal. can. \$I.25; I doz. I gal, cans in case, per case, $\$ 9.00 ; 3$ doz. I qt. cans in case, per case, \$10.50; Io gal. cans in case, per case, $\$ 6$ 25; barrel, containing 50 gal, 6oc. per gal. 


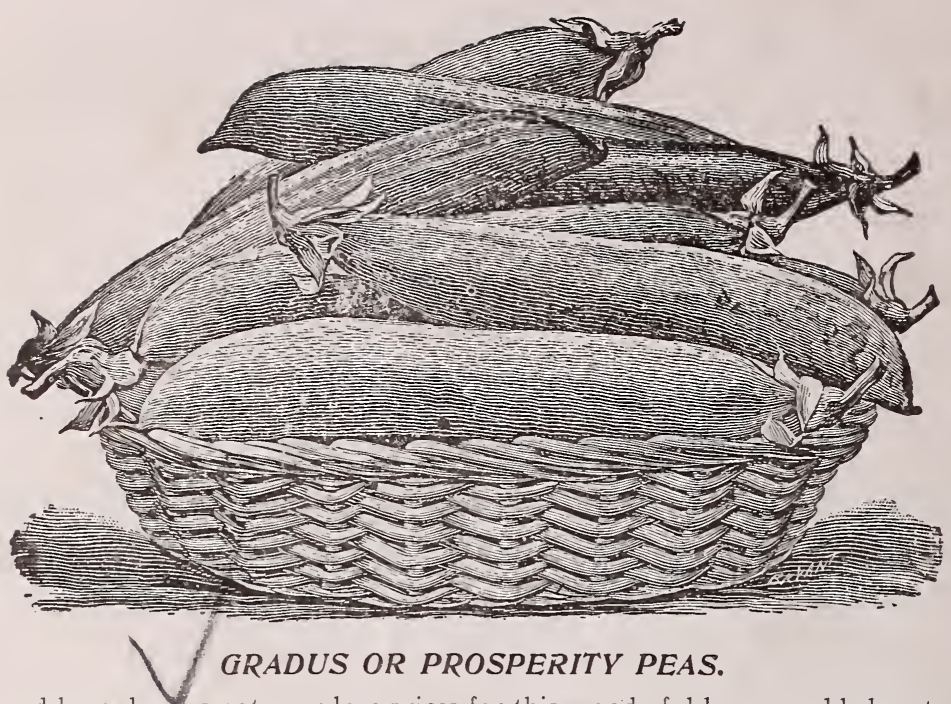

Truckers and large buyers note our low prices for this wonderful large podded extra early sort, see page I9. Seed splendid samp!e this year. Qt.. 40c; pk., \$2.8o; bu, \$7.7j; io Du. \$75.00.

Thos. Laxtox Peas. Qt., 30c; pk., \$1.75; bu., \$6.00; io bu. \$35.00.

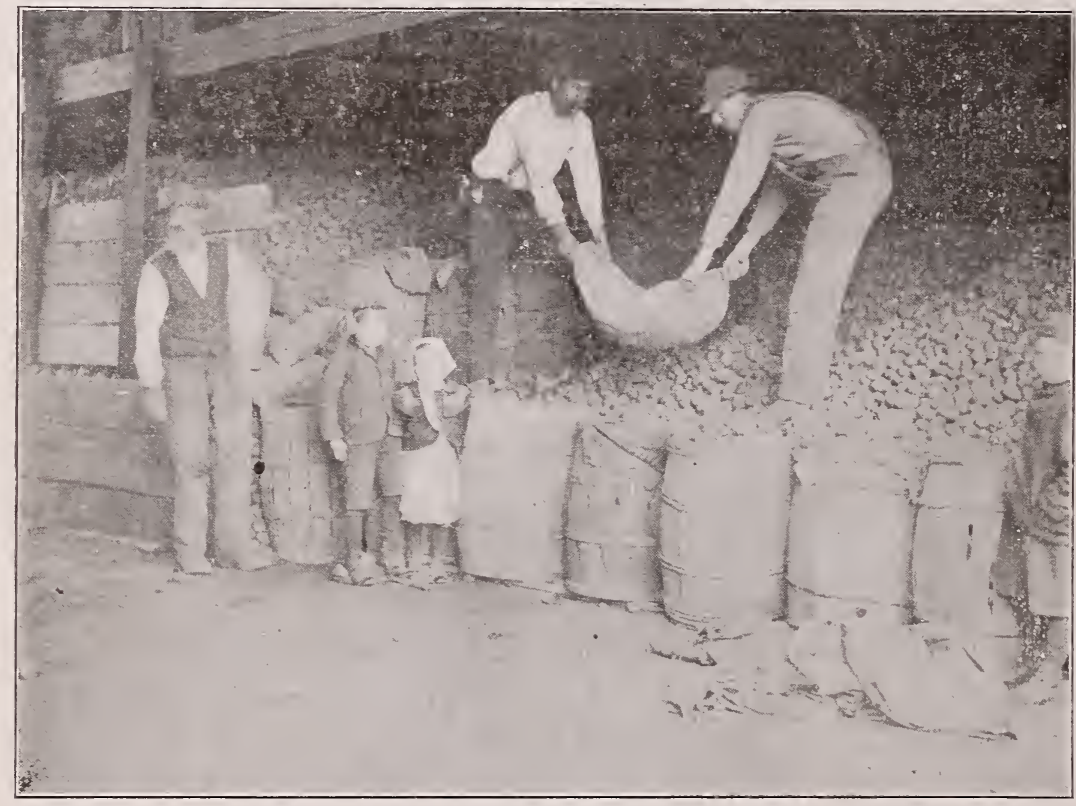

Photograph of a bin of Green Mountain Potatoes raised by Mr. J. A. IIughes of I.ong Is'and, one of the hundreds of up-to-date trucliers, whose entire crop from a large acreage averaged orer ico barrels per acre last season. Mr. Hughes uses our northern grown seed and seed potatoes.

\section{S. D. WOODRUFF \& SONS,}

\section{Orange., Conn, and 82-84 Dey St., New York City.}

